\title{
The long-term ecology of agricultural terraces and enclosed fields from Antikythera, Greece
}

Bevan, A., Conolly, J., Colledge, S., Frederick, C., Palmer, C., Siddall, R. and Stellatou, A.

Postprint of paper in Human Ecology 41.2

\begin{abstract}
Terraces are ubiquitous, in some ways defining, features of Mediterranean environments, yet their longer-term history and relationship to human populations and food economies are not well understood. This paper discusses a complete system of terraces across the small island of Antikythera, Greece. We bring together the evidence from archaeology, ethnography, archival history, botany and geoarchaeology, supported by direct dating of buried terrace soils, and consider terrace investment in relation to major episodes in the island's punctuated history of human activity. This broad-spectrum approach leads to a range of interesting insights on the spatial structure of terraces, on the degree of correlation between terrace construction and changing human population, and on the implications of terrace abandonment for vegetation and soils.
\end{abstract}

\section{Introduction}

Antikythera is a small (20.8 sq.km) and in Mediterranean terms comparatively remote, Greek island situated half-way between Kythera and western Crete in the southwest Aegean (figure 1). Since 2005, it has been the subject of a phased, interdisciplinary program of fieldwork and laboratory analysis that addresses its long-term history and human ecology. One important aspect of this research has been a focus on recurring, non-mechanical landscape investments that usually have an anticipated use beyond the current farming cycle and/or over many human generations. These include often complex and extensive systems of fields, trackways and terraces (as well as certain kinds of long-lived orchard), are sometimes called landesque capital (e.g. Blaikie and Brookfield 1987: 9-10; Widgren 2007) and are an important form of niche construction for small-scale famers (Odling-Smee et al. 2003). They are also characteristic, almost defining, features of Mediterranean landscapes from at least the Bronze Age if not before.

In this paper, we focus our attention on the most cross-culturally well-known case of landesque capital, agricultural terracing. Such systems can be constructed in a variety of ways, with both negative and positive effects on the visibility and preservation of archaeological remains (Whitelaw and French 1999). Terraces can be of some antiquity, but are notoriously difficult to date (Frederick and Krahtopoulou 2000). In spite of their clear importance throughout much of past Mediterranean history and obvious relevance to modern concerns about sustainable food production, water management and erosion control, the social context in which agricultural terraces emerge is as yet poorly understood. They have received scholarly attention in a variety of semi-arid to tropical 
environments (e.g. Marcus and Stanish 2006), with population pressure, competition for territory, and/or politically-motivated mega-projects, as well as the resultant incentives to bring marginal hillslopes into cultivation, often invoked as explanations for the expansion of terrace systems (e.g., Mazoyer and Roudart 2006: 196); but an increasing emphasis on 'bottom-up' processes and emergent complexity reflects a growing concern of how individual and community cooperation over the long term can result in complex agricultural systems (e.g., Erickson 2006). A recent review of the published Aegean literature on these structures arguably identified a wider malaise in our understanding of terrace formations world-wide and noted a surprising lack of knowledge about the relationship between terrace systems and the wider social context behind their development (Price and Nixon 2005).

A study of Antikythera's terraces enjoys, in our view, several advantages over a comparable study in a different Mediterranean landscape. First, we can acquire a near complete sample of the terraces built during the latest phase of the island's occupation. Second, we can address earlier phases of terraces in tandem with an equally island-wide intensive archaeological survey of Antikythera's long-term settlement patterns (Bevan et al. 2008). Third, the island's exhibits dynamic history of human exploitation, including phases of both substantial settlement and near complete abandonment, that is analytically more convenient that the complex conditions that often exist in other regions. More precisely, most previous descriptions of landesque investment in the Mediterranean (including those on larger islands) have grappled with a frustrating palimpsest of landscape features, spanning long time periods and often different, mixed groups of inhabitants (e.g., James et al. 1997: 27-28). Such studies have also typically conducted their investigations in a series of small, patchy landscape samples. In contrast, and a fourth and final advantage, we can often collect a range of other relevant cultural and environmental variables systematically and comprehensively across the island.

This paper draws together several different strands of archaeological, ethnohistorical, geoarchaeological and botanical research to offer an integrated perspective on agricultural terraces as a form of landscape capital. It begins by summarising the aggregate patterning of visible terrace systems on the island, emphasising how this relates to key environmental variables such as the island's geology, topography and climate. It then places these structures and correlations within a broader ethnohistorical context, particularly with regard to land use and population over the past 250 years. Thereafter, we address the geoarchaeology of Antikytheran terraces more closely and consider their potential impact on soil fertility and erosion on the island. An associated issue is the potential impact when terrace systems are abandoned (either wholesale or in part) and the subsequent process of recolonisation by local plant communities (Palmer et al. 2010). We therefore assess the tempo, character and overall importance of vegetation succession in abandoned fields. The final section adds time depth to our understanding of Antikythera's terraces - via a combination of radiocarbon dating, optically-stimulated luminescence dating and more circumstantial archaeological evidence - to suggest repeated cycles of terrace construction and how these might relate to changing demography and land use. 


\section{The Geoarchaeology of Antikytheran Terraces}

It is clear from our wider work on the island that, as one might expect, geology plays a fundamental structuring role with respect to episodes of past and present human activity, despite the fact that Antikythera is an almost wholly limestone island (figure 2; see also Bevan and Conolly 2009), with no outcropping of the kinds of metamorphic, phyllite zone that are found in neighbouring regions of Kythera and western Crete. Apart from this, it represents a classic section of southern Greek geology (Galeos and Drandaki 1993; Kokinou and Kamberis 2009), exposing carbonate rocks of Gavrovo-Tripolitza type (Upper Cretaceous, rudist-bearing limestones along with nummulitic limestones of PalaeogeneMiddle Eocene age) and its overlying flysch (sandstone of Upper Eocene age). Post-Alpine Neogene extensional tectonics produced sedimentary basins collecting shallow marine and shore facies rocks, in places accumulating marls and conglomerates hundreds of metres thick. Thin strips of Holocene alluvium also occur at various locations, but none of these are extensive.

\subsection{Terracing and Overall Landscape Structure}

Our mapping of Antikythera's terraces involved systematic ground-truthing across the whole island that benefitted from the availability of aerial photographs taken in 1944 and a high-resolution Quickbird satellite coverage from 2004 (figures 3a-b). In total, over 12,000 relict enclosure walls and terraces are clearly visible (and were individually mapped as vector polylines: figure $3 c$ ), with the suggestion of more ephemeral traces in several further locations. Relict agricultural terraces are particularly visible over approximately $30 \%$ of Antikythera's 20.8 square km: stepped, hillslope terraces and cross-channel terraces are the two main types, while other forms, such as braided terraces which zig-zag up a slope, are rare. As has been described in other regions of the Mediterranean, terrace type is often related to underlying geology (Grove and Rackham 2001: 107), but can also vary according to different cultural traditions of riser and tread construction (Frederick and Krahtopoulou 2000). Two main types of riser construction are present, those built of even-sized cobbles (of either Neogene or Cretaceous limestone) and those made with a combination of large upright Neogene slabs and filler stones (figure 4c-d; also Price and Nixon 2005: 12).

There are several other notable features about the field systems on Antikythera. First, there is no abrupt separation between enclosed flat fields and terraced hillslopes. Instead, even the enclosed fields in flatter areas almost always comprise one or more walls that that are not entirely freestanding and instead hold in soil on a slight slope, with this role merely becoming more prominent as slope steepness increases. As a result, it is difficult to suggest a specific slope angle at which terracing effectively starts and flat field agriculture ends, in contrast to the clearer separation of these two regimes on Kythera to the north (contrast figure 5a with Bevan et al. 2003: figures 1-4; also Krahtopoulou and Frederick 2008). 
Second, spatial modelling demonstrates a significant negative relationship between the presence of agricultural fields on the island and both proximity to hard limestone and steepness-of-slope, but a positive relationship with distance from the coast (Bevan and Conolly 2011). Put simply, field systems on Antikythera have been preferentially constructed on the softer marl and flysch geologies, in flatter areas and at some remove from the coast (which is often rocky and exposed to sea-spray). In addition, above and beyond the influence of these variables, agricultural terraces and flatter fields are typically found in clumped patches (up to ca. $400-\mathrm{m}$ radius), which we interpret as reflecting an agglutinative tendency whereby terraced plots are brought into cultivation in groups (by one or a few families) and existing terraces encourage the construction of neighbouring ones. The landscape of villages, isolated farms and field shelters is also one that has coevolved with that of the fields themselves (figure 5b, and for further assessment of these interpdenedencies, see Bevan and Conolly 2011).

Third and finally, it is worth noting one peculiar type of terrace setting on Antikythera that, again, is not nearly so common on Kythera: cross-channel terraces that run up steeply sloping tectonic trough valleys within the harder limestones (figure 3a). These valleys are fault-bounded linear, typically water gathering slopes which often have a prominent high bedrock wall on one or both sides. They are scattered widely across the island, follow the prevailing NNWSSE tectonic fault lines, and are usually cross-channel terraced where present, particularly in cases where the bedrock wall offers some protection from westerly winds.

\subsection{Construction Techniques and Terrace Soils}

Turning to the structure of terraces and terrace soils, the relative height of the terrace riser and spacing between terraces appears to correlate at least in part with bedrock geology and associated soils. The harder (rudist-bearing and nummulitic) limestones rarely exhibit tall terraces, with most examples less than $50 \mathrm{~cm}$ high, spaced quite closely (dependent on slope steepness but often less than $10 \mathrm{~m}$ apart) and sometimes exploiting bedrock outcrops for the riser wall foundations. The main reason for this pattern may be the heavier weight of both the rock and the clayey terra rossa soils in comparison, for instance, to the Neogene marls. Furthermore, the initial construction of such short terraces appears not to have involved much movement of earth and rock, and as a result, they often just thicken the existing A horizon, rarely preserve buried soils (one observed exception is a buried soil horizon from a terrace on hard limestone in a tectonic valley, figure 1: KL1) and often preserve only one visible phase of use. It is also rare for such short terraces to fail catastrophically and, as a result, opportunistic exposures in these landscapes are usually limited to road cuts.

Single-phase terraces on the Neogene deposits appear, more often than not, to be relatively thick (generally $>1 \mathrm{~m}$ ), more widely spaced and more carefully constructed. Furthermore, in numerous road cuts and exposures revealed by fallen riser walls, these terraces fossilised the soil that existed on the surface at the time the terrace was constructed. In many heavily terraced areas of the Neogene outcrop, the riser walls are quite high (2-3 $\mathrm{m}$ or more) but often the 
wall height is largely due to the riser extending downslope below the tread fill, thereby protecting a bedrock outcrop as well as retaining the constructed tread fill. Perhaps because the riser heights are greater, or also because the loamy textured tread fills are more friable, the terraced Neogene landscapes appear to be considerably more erosion prone (see below).

As a result of the parent bedrock formations present on Antikythera, as well as localised patterns of Quaternary soil formation and later Holocene land use, soil fertility across the island is quite variable. Antikytheran soils today do not exhibit a particularly heavy salt load despite the fact that we might assume this to be a major problem for such a small and comparatively exposed island. Almost all of the soils are alkaline with comparatively high $\mathrm{pH}$ levels, and related to this, comparatively low levels of zinc (figure 6). They are also very low in phosphorus and comparatively high in magnesium, particularly on the older, harder limestones. This is unsurprising given that phosphorous is a non-stable element which is particularly likely to decline in dry, alkaline soils (Bohn et al. 2001: 4748) and magnesium is typically high for soils forming on limestone (i.e. where calcium magnesium carbonate is present). The low-levels of phosphorus probably reflect the fact that most cultivated areas have fallen entirely out of agricultural use and are not intensively manured. More interestingly, the potassium levels in the Antikytheran soils are very elevated, although this is likely due to natural accumulation, which has been observed in other semi-arid locations in the Mediterranean (Sarah 2004). Indeed, most of these observations find correlates more widely in abandoned agricultural soils from other parts of Greece, with one of the earliest systematic studies noting many instances of low phosphorus, high magnesium and comparatively high potassium (Bouyoucos 1922: 75). The Antikytheran samples are merely a fairly extreme example of this phenomenon and in our view, this points to particular kinds of grazing behaviour (e.g. of goats on the harder upland limestones) as a key factor effecting soil fertility in this region after the cessation of agricultural activity.

It was also very clear in the harder limestone landscapes on Antikythera that the terracing process led to the creation of particularly stony surface soils we see today, as a result of exhuming the rotted bedrock with clay from the back end of each terrace. The naturally occurring terra rossa clays become progressively stonier with increasing depth, but near the ground surface they appear to have been relatively stone free, except for a thin surface crust of gravel. The same is probably true of all terraces in this landscape where the bedrock soils are stony or easily excavated. Hence terracing tends to yield gravel-armoured surfaces that look more imposing to cultivation than they are in actuality, especially after they have been abandoned.

Finally, the role of terraces in preventing soil erosion is a heavily discussed topic and not one that we will tackle in detail here (see Bevan and Conolly 2011). Certainly, collapsing terraces and eroding hillslopes now tend to be linked, practically and emotionally, with the loss of traditional community life and social cohesion, but it is worth noting that preventing soil erosion is rarely a motivation that we can document ethnographically amongst terrace builders in the recent Mediterranean, or via older historical records (Grove and Rackham 2001: 259- 
260), Regardless, it is certainly true that the conversion of hillslopes to agricultural fields alters the soil properties and vegetation cover of a potentially vulnerable part of the landscape, and both this initial effort at agricultural expansion and any subsequent abandonment can have dramatic effects (Butzer 2005).

\section{An Ethnohistorical Perspective}

In this section, we move on to consider a range of historical documents and ethnographic testimony (by some of the island's older current inhabitants) that offers a vivid picture of expanding and then contracting agriculture during the $19^{\text {th }}$ and $20^{\text {th }}$ century AD, and thereby place the human motivations for the most recent phase of terracing on the island into greater context. These sources make it clear that the island was recolonised by several families from west Crete (primarily from Sphakia) in the last quarter of the $18^{\text {th }}$ century, Thereafter, during the $19^{\text {th }}$ and earlier $20^{\text {th }}$ century, it supported several small villages with an overall population ranging from a few dozen to a sustained threshold of several hundred, and briefly, over a thousand people (figure 7a). The amount of land that informants suggest was owned by each family varies greatly during the last century (from 1.5 hectares to 15 hectares), but land transfer from generation to generation seems to have followed rules of partible inheritance that are common in recent Greek history (Forbes 2000), leading to plot sizes that were frequently quite small (e.g. typically less that $0.4 \mathrm{ha}$ ) and spatially-scattered.

Until the later $20^{\text {th }}$ century, the island economy was primarily agricultural, based on a mix of cereals (wheat, a wheat/barley mix, possibly maize and some oats), legumes (fava beans, broad beans, chickpeas), some vines (for making wine), a limited array of orchard fruits (lemons, almonds, figs but only a very few olives) and some garden vegetables (flax, cotton, tomatoes, aubergines, peppers, courgettes, sesame, various green leaf plants), as well as the herding of livestock (mainly goats, but also a few sheep, pigs, donkeys and plough oxen). Most cereal and legume crops were grown within enclosed fields and terraces, often in a two or three-year rotation (including one year of fallow), while sheep and goats grazed the island's rockier slopes. Very few of the remaining inhabitants on Antikythera have any memories of terraces actually being built on the island (these structures are typically referred to by their common Greek name pezoulia, or the local term chalastres) and the community consensus is, as is the case elsewhere in the Mediterranean, that most terraces were constructed prior to the 20th century (e.g. Grove and Rackham 2001, 107; and for regions neighbouring Antikythera: Krahtopoulou and Frederick 2008; Price and Nixon 2005). Even so, several remember September as the month in which it was customary to repair terraces: after the main cereal harvest, before the first rains and in tandem with other maintenance task such as clearing stables, collecting winter firewood and insulating house roofs.

Of particular interest are the earlier $19^{\text {th }}$ century agricultural records kept by the British administration responsible for the island at the time. These documents are well preserved for the period 1826-47 and indicate a phase of rapid agricultural expansion during which the amount of declared land under crop increased from $7 \%$ to $43 \%$ of the island (figure $7 \mathrm{~b}-\mathrm{c}$ ). Throughout the recording 
period, the amount of pure wheat farmed on the island remained only a very minor component of overall crop (20-25 ha, or 3-4\%), with either cereal mixes and/or maize being preferred. Both the overall area of land under crop and pasture and the amount declared as cleared and potentially cultivable increased by a factor of three or four. Even so, this pattern of increase does not match the patterns of variation in population over this period, at least as if we measure it at a decadal or sub-decadal scale. For example, the large spike of immigrants in 1824-5 was sue to an influx of political refugees, but these do not lead to any immediate or delayed incorporation of new land into cultivation. Rather it is only in the 1830s and 40s, during a period of slight population decline, that we see the latter agricultural expansion occur.

This pattern suggests that immediate pressure imposed by the increasing human population were not the main or only factor behind terrace building and associated agricultural expansion in the period. Instead, we have a pattern that fits well with the historical sources, to the effect that direct political encouragement and conducive regional markets were important. First, the enclosure of and physical investment in new tracts of land was part of a deliberate strategy within the Ionian islands at this time, promoted both through agronomic advice and tax exemptions for newly-exploited and enclosed land (Jameson 1836: 274; Leontsinis 1987: 217-41). Second, this was also a period of increased overall maritime connectivity, new regional markets for goods, and relaxed conditions for cross-border economic relations (e.g. with Ottomancontrolled Crete where many Kytheran and Antikytheran families had longstanding ties). In any case, the shift in production during the later 1830s and early 1840 s moved the island abruptly away from one in which cereals were providing only the bare necessities in terms of a cereal contribution to the diets of permanent local inhabitants (ca. 1000-1500 calories per person if we assume typical calorific values for the main cereal crops and exclude about a quarter of the crop that was kept as seed for the next year) to double this and the generation of a cereal surplus that was reportedly exported on a regular basis.

Figure $7 d$ plots the yields for wheat and other mixed cereals that is implied by the island's early $19^{\text {th }}$ century produce and cultivated area statistics ${ }^{1}$ and suggests some interesting patterns. Overall, it is clear that the cereal yields on Antikythera were pretty low, by comparison both to contemporary returns on neighbouring Kythera, and those in Greece as a whole over the past 150 years. $^{2}$

\footnotetext{
1 The yields were calculated from original records of the number of acres under different kinds of cereal crop and the overall number of bushels these produced. The 'mixed cereals' category reflects an undifferentiated grouping used in the Ionian state statistical returns for 'Indian corn [maize], barley, calambochio and smigadi'. Smigado (a mix of wheat and barley produced by intercropping) is a well-known strategy for ensuring a baseline harvest in this region particularly in what are perceived as marginal areas. The relative importance of maize is less clear, with contrasting suggestions that it was both common and rare on Kythera and Antikythera at different times (Jameson 1836: 276; Leontsinis 1987: 233-5).

2 Comparing yield figures can be problematic, but as a very rough guide, average wheat-only yields in tons/ha for Antikythera in 1826-39 and 1840-47 were 0.44, and 0.33, compared to Kythera (1826-39, 1840-47): 0.55, 0.55; and Greece (1860, 1887, 1914, 1960s, 1970s, 1980s, 1990s, 2000s): 0.89, 0.91, 0.75, 1.56, 2.22, 2.64, 2.48, 2.37 (data from UK National Archives CO 136/1332-40; Bouyoucos 1922: table 1; Christakis 2008: tables 2-3; http://faostat.fao.org/; and
} 
The figures in figure $7 \mathrm{~d}$ also suggest not only an increasing consistency, but also an overall decline in recorded yields after 1840. Decreasing overall yields are part of a phenomenon also documented for the neighbouring island of Kythera (Leontsinis 1987: 236-7, with a larger dataset and over a longer period) and might conceivably suggest one or more of: (a) declining overall soil quality; (b) a reduced intensity of agricultural investment per field; (c) a shift away from planting cereals on the most fertile fields; (d) the incorporation of more marginal landscapes into production. At present, the evidence does not allow us to discriminate conclusively between these different possibilities, but several factors suggest that the incorporation of more marginal land into cultivation was particularly important. First, the new areas of the landscape being enclosed and planted with crops were the more marginal ones (to judge both from the archaeological remains and the memory of older modern informants), and field observations suggest that the least-invested field systems (in terms of stone clearance, haphazard terrace construction, etc.) are found in upland slopes on the harder limestones where very extensive, broadcasting of cereals is the most likely strategy (particularly in the early stages of their exploitation when production of a viable crop was often likely to have been an annual bonus rather than a core concern of the families involved). Second, there is much higher interannual variation in the yields declared before 1840, and while some of this variation is likely to have been due to varying rainfall (particularly over the spring season where these variations have greatest impact on crop returns), we would argue that the much more consistent returns from 1840 onwards also probably reflect shifts in agricultural practice, with more marginal land sown in a less haphazard way, more formally invested with walls etc., and increasingly declared as actual fields.

\section{Abandoned Terraces and Recolonising Vegetation}

Figure 7 a charts a demographic trajectory that is arguably common on small islands (indeed mathematically probable: Williamson and Sabath 1984), with a successful initial colonisation phase followed by population increase and occasional sharp spikes due to off-island events, eventually followed by demographic decline and near abandonment. The latter stages of this process are when the most recent process of terrace abandonment seems to have startednot helped by the fact that most of the able-bodied population of the island was temporarily forced to move to Crete by occupying German authorities during the Second World War. After the war, agricultural life resumed to a degree, but cereal farming largely disappears by the late 1980s and early 1990s, and only a few scattered vegetable gardens and vineyards continuing to be maintained today. The vegetation groupings studied on Antikythera can broadly be classified into cultivated land (vineyards and horticultural plots; terraces with herbaceous vegetation, phrygana and low maquis) and unterraced land dominated by low or high maquis (for our preferred definition of these communities see Turland and Fielding 2005, 33). However, as the scale of human management of the island's agricultural landscape has declined, the local flora has adapted and recolonised. Our botanical work on the island therefore focused on understanding if the

for overall rising 20th century wheat yields in Mediterranean due to careful selective breeding, see for example Sener et al. 2009). 
period since terrace abandonment can be estimated based on floristic composition, and the extent to which the character of recolonising vegetation is correlated with underlying geology. We studied the vegetation communities present in 13 different quadrats at six representative locations, covering each of the main geological zones. By a variety of methods (e.g. aerial photographs, local informants, geoarchaeological evidence) we were also able to develop rough, non-floristic assessments of whether our sample areas were only recently abandoned, abandoned some time ago or never cultivated (or terraced), providing a useful independent check on the botanical results.

Full details of this botanical study are published elsewhere (Palmer et al. 2010), but two key conclusions to note here are that there is an extremely clear succession to the way vegetation has recolonised abandoned fields on Antikythera (figure 8), and that, at least for the limited range of formations present on the island, this is not strongly affected by variations in bedrock geology. More precisely, plant taxon diversity is clearly correlated with our independent observations of different land use histories. For example, diversity is higher both on plots that were recently farmed and in unterraced areas without any signs of prior cultivation. After terraces are abandoned the diversity of plant species declines, but then, in time, increases again.

Recently abandoned terraces contain a relatively rich, low herbaceous flora while longer abandoned terraces document a transformation of the vegetation into a more typical phrygana type, where small pillow mounds of thorny burnet (Sarcopoterium spinosum) and conehead thyme (Coridothymus capitatus) dominate. Diversity decreases as the time since abandonment increases, but after a much longer period of disuse this is reversed and species richness increases again, but with a markedly different composition. In recently abandoned terraces the numbers of annuals are high, whereas in unterraced areas, low maquis (which comprises many perennial species) is dominant. After longer term abandonment the proportion of annual species seems to decrease as perennials invade and become established. A combination of evidence (including landowner testimony and assessment of successive aerial or satellite photo coverages from 1944, 1988 and 2004) also allows us to put rough dates on this pattern of vegetation succession and suggest that woody perennials, beginning with phrygana, begin to dominate abandoned terrace vegetation 20 to 60 years after cultivation ceases (in rough agreement with Koulouri and Giourga 2007). An interesting feature of these results is that this vegetation succession is clear despite differences in bedrock geology and despite the presence of many grazing goats, both factors that have previously been thought to lead to variability in the character of post-abandonment succession or to impede its progress (Tzanopoulos et al. 2005; Papanastasis 2007; Rackham 2008: 58).

\section{Earlier Phases of Terracing}

So far our discussion has addressed the agricultural field systems on Antikythera from a synchronic perspective and/or with an implicit focus on the latest phases of construction, given that it is on these that we can bring to bear the widest range of disciplinary perspectives. While the current administrative frameworks governing geological and archaeological research in Greece make it difficult to 
combine both surface reconnaissance with widespread sub-surface trenches into abandoned fields (even if local landowners are willing), recent road-building activities on the island and many fallen terrace riser walls nonetheless provide opportunistic sections, with roadcuts being especially useful as they typically penetrated through to bedrock and often were laterally extensive. Multiple, superimposed phases of terracing were observed in several areas, but rarely if ever in the harder limestone landscapes. Although this could be, at least in part, an artefact of impaired visibility (owing to fewer exposures in the latter landscapes), it probably implies that these were less preferred agriculturally, and resorted to only when the Neogene marls and Eocene flysch areas were already owned or otherwise in production. Multiple phases of terracing were observed on both the Eocene flysch and the Neogene marl and in many cases the earliest phase was observed resting directly upon the bedrock (see below). In some cases, this may indicate that terracing represents reclamation of land that had already been eroded by either natural or anthropogenic causes, but in some cases where these first phase deposits are slightly reddened (often with a 7.5YR hue) then they may well have been the result of exploiting patches of B horizon that existed immediately upslope of the riser.

Geoarchaeological documentation of terrace exposures took four main forms: (i) detailed field descriptions, (ii) photomosiacs with associated field sketches and annotations, (iii) samples of stratified soil horizons for broad spectrum nutrients and granulometry, and (iv) further soil and/or charcoal samples for radiocarbon and optically-stimulated luminescence dating. Below, we discuss four areas of terrace section exposed in road-cuts, before moving onto more circumstantial archaeological evidence.

\subsection{Road-cut evidence}

\subsubsection{Domata Plateau (D1 and D2)}

Two short road-cuts through contour terraces on the upland plateau were investigated just south of the modern village of Galaniana (figure 1, D1 and D2). This landscape is underlain by the Upper Cretaceous rudist-bearing limestone and the soils are prominent clayey terra rossas. Prior to terracing, this landscape was gently eastward sloping and exhibited a range of karstic exposures consisting of upstanding earthfast bedrock outcrops interspersed with microbasins of terra rossa red clay. The terraces here are generally quite small in height, generally less than half a meter. As a result, there are very few fallen walls and no natural exposures of the terrace deposits. Two road cut exposures close to one another exhibited similar stratigraphy (figure 9). The first exhibits a $45 \mathrm{~cm}$ thick Ap horizon resting upon a redder Bt horizon. The second, about two risers upslope of the first, is a relatively narrow contour terrace with a $3 \mathrm{~m}$ wide tread, the upslope or rear of which had a number of exposed bedrock outcrops. A column of soil samples was collected from the leading edge of the upper terrace where the terrace fill was approximately $30 \mathrm{~cm}$ thick and also rested upon an argillic horizon. Analysis of these samples indicates that there was a thin A-horizon formed at the top of the Bt horizon between $25-30 \mathrm{~cm}$ below the surface, as is indicated by subtly elevated values in loss-on-ignition and the magnetic susceptibility, as well as slightly less calcium carbonate, but this vestige 
of the former topsoil was not observable in the field. The terrace fill exhibits a relatively homogeneous gravelly silty clay texture and is notably less clayey than the underlying argillic horizon. Although the landscape in this area has undoubtedly been used over a very long period in part centered on the flyschfilled doline depressions which dot its surface (and around which there is archaeological evidence for concentrated activity going back 4-5,000 years), the terraces on this slope appear to be attributable to a single phase of terracing in the19th century AD.

\subsubsection{Galanania (M1 and M2)}

Moving northwards, the most complex terrace section we examined was a roadcut north of the church of Agios Myronas in the village of Galaniana (figure 1a, M1 and M2). This road cut exposes a sequence of deposits that fill in a narrow water-gathering slope cut into flysch that today is cross-channel terraced. The road-cut exhibits at least two phases of terracing, apparently separated by a period of abandonment. Two vertical profiles were cleaned, described and sampled in order to document the deposits present. One of these was a $2 \mathrm{~m}$ long profile through the centre of the cross-channel terrace (M1) and a second vertical profile (M2) was collected to one side of the centre of the watergathering slope on what appears to have been a relatively flat, contour terraced bench that bordered one side of the narrow stream valley (and a similar bench was present on the other side of the narrow water gathering slope).

The results of the analysis of these profiles are listed on shown in figures 10-11. The initial phase of deposition in this sequence lies about $1.5 \mathrm{~m}$ below the modern ground surface in the centre of the water-gathering slope. This deposit comprises a fining upward body of sediment that is a loam at the base and grades up into a silty clay loam. A prominent buried soil (an A-horizon) has formed in the top $20 \mathrm{~cm}$ of this deposit. This deposit may be the vestiges of a cross-channel terrace but that could not be confirmed in the field. The decrease in calcium carbonate and elevated loss-on-ignition and magnetic susceptibility values within this buried topsoil suggest that this surface was stable a prolonged period and a radiocarbon age on the bulk organic matter in the soil indicates it was buried around 1,000 to 800 years ago (920 \pm 40 years BP; cal AD 1042-1159; Beta-248595). The presence of two suites of large boulders on the top of this buried soil at the margins of the water gathering slope are interpreted as the remains of failed stone terrace risers that paralleled the valley axis and that were perched immediately above the valley floor. Two phases of terrace construction were noted in the short profile (M2) but the radiocarbon age obtained from a piece of charcoal collected from the older of these yielded an age $(230 \pm 40$ years BP; AD 1641-1951; Beta-248599) that fails to support this interpretation and most likely represents use of the upper terrace in the last 500 years. On the valley floor, the remains of the fallen terrace walls were buried by a new sedimentary deposit that later stabilized (as indicated by a top soil formed in this deposit). This sediment was most likely associated with gully erosion of the terraces flanking the water-gathering slope that would have created small alluvial fans on the valley floor. Eventually, this new deposit covered the entire valley floor in a relatively flat blanket, and this most likely occurred as part of 
terrace rehabilitation and the construction of a new cross-channel terrace wall. In profile M1 this new deposit was about $40 \mathrm{~cm}$ thick, fined upward, and after it was deposited, there was about one half meter of relief separating the terraces along the margin of this small valley and the valley floor. With the passage of time a new soil formed in this new deposit and this A-horizon was quite organic rich (similar to the modern terrace surface with loss-on-ignition values around $5 \%$ ), exhibited slightly elevated magnetic susceptibility and had been leached of calcium carbonate in the upper $15 \mathrm{~cm}$, all of which indicate it stood as a stable surface for some time. A radiocarbon age on bulk soil organic matter from the top of the buried soil indicates that this surface was buried around or after cal AD 1333-1439 (520 \pm 40 years BP; Beta-248596) by the construction of the modern cross-channel terrace system.

The most recent phase of terrace construction buried the flanking contour terraces and valley floor to form a single, much wider cross-channel terrace. About one half meter of new sediment was added to the flanking terraces, and about one meter of new sediment was deposited in the centre of the valley during this phase of terrace rehabilitation. This deposit generally coarsens upward, reflecting the new sediment was derived directly from excavation of the flysch bedrock. The properties of the deposit in centre of the valley suggest that this renovation could have occurred in two phases marked by a very short term stabilized surface around $40 \mathrm{~cm}$ depth in the profile $\mathrm{M} 1$, but only one phase was clearly visible in profile M2 along the margin of the water-gathering slope. This new terrace deposit has been present for only a short period of time and as a result exhibits the least evidence of soil development. The soil formed in the top $40 \mathrm{~cm}$ of the deposit exhibits relatively high organic matter content (loss-onignition values of $4.6 \%$ near the ground surface) but show neither significant leaching of calcium carbonate nor evidence of magnetic susceptibility enhancement.

Overall, the deposits exposed here are consistent with initial phase of terracing during the Middle Byzantine to Early Venetian period or earlier, followed by a period of abandonment and subsequent failure and erosion of the first terraces. The next clear phase of terrace construction is the most recent one, and most likely belongs to the period of late $18^{\text {th }}$ century re-colonization, and it may have witnessed incremental changes that are finer than the chronological resolution of the dates we obtained. The deposit in the centre of the valley between these two clear terrace construction phases looks like a period of cross-channel terrace use in the 13th to 15th centuries, with the earlier part of this range fitting better with the present picture of human settlement from surface archaeology.

\subsubsection{Charchaliana (Ch1)}

This section was exposed by the fallen wall on a contour terrace, which is one of several terraces lining the north-bank of a shallow gorge on the western side of the island (figure 1a: Ch1). The terraced slope is situated on Neogene marl/limestone (a gravelly bed of which is exposed upslope and is incorporated into the terrace deposits) and is quite steep (ca.15-20 $)$, with a succession of fallen terrace riser walls creating short exposures with what appears to be 
similar local stratigraphies. A short distance to the east, the Neogene series laps onto the upper Cretaceous rudist bearing limestone. All of the land lining the gorge that could be terraced is, and even the floor of the gorge has been crosschannel terraced, despite it being relatively steep and at risk of flash-flooding.

The documented exposure appears to represent two phases of terracing (figure 12). The stone riser of the earliest terrace rests directly upon the Neogene marl, appears to have been about $50 \mathrm{~cm}$ tall and had a gently sloping tread. There is no clear remnant of an A or B horizon on the marl, which suggests that this first phase construction followed a period of soil erosion. The now buried topsoil of the first terrace articulates to the riser of the existing terrace, clearly indicating that this was a terrace and not a natural colluvial deposit. The core of the tread fill of the first phase terrace (Zone 3) exhibits a 7.5 YR hue, and may represent a $B$ horizon that was incorporated to form the tread fill (a point supported by the elevated magnetic susceptibility of these deposits), and the upper half of the first phase terrace appears to have been derived from Neogene marl. In the sampled section all of the sediment comprising the terrace fill appears to have been moved and/or tilled. Identifiable pottery fragments collected from the tread fill of the first phase terrace was all firmly 5th-7th c. AD (three fragments of groovedecorated Late Roman amphorae and one bowl rim from an African Red Slip D, Hayes type 67A) which indicates either that the sediment borrowed to create the terrace was either contemporaneous with or post-dates this period, or that this deposit was used during this period. This is seemingly at odds with a single grain OSL date obtained from near the top of zone 3, just below the buried A-horizon, which yielded an age of $2280 \pm 130$ years BP (402 BC to 142 BC; Shfd-08110). That said, the sand grains dated from this deposit were last exposed to sunlight in the period ranging between 1133 to 3899 years BP (AD 875 to 1891 BC) which suggests that this terrace may have been constructed during the Middle Bronze Age and continued in use through the Late Roman period. Organic matter within the A-horizon of the first phase terrace yielded a radiocarbon age of $510 \pm 40$ years BP (Beta-248598), or cal AD 1404-1440) which suggests that the second phase terrace was buried at this time or slightly after. It is likely that this radiocarbon age is slightly older than the actual burial date owing to a mean residence effect in the soil organic carbon pool.

The second phase terrace construction raised the height of the riser about $80 \mathrm{~cm}$ but only extended the flat-lying tread a small amount, and where sampled the second phase terrace deposits were about $35 \mathrm{~cm}$ thick. The low magnetic susceptibility, high calcium carbonate content and relatively coarse texture of these deposits suggests that sediment for the second phase terracing was obtained by excavation of the Neogene Marl at the rear of the tread. The topsoil of the second phase terrace contains about the same amount of organic matter but exhibits no magnetic susceptibility enhancement, which implies a young age. A single grain OSL sample was collected from the upper terrace fill at a depth of $27 \mathrm{~cm}$, and this sample yielded an age of $150 \pm 30$ years BP (one sigma age range of AD 1828 to 1888). Grains measured from this deposit included three that had been exposed recently and $81 \%$ were exposed to sun within the last 500 years. Half of the measured grains were exposed to sun between 100 and 500 years ago, and only a few $(\sim 18 \%)$ were exposed to the sun between 500 and 1560 
years ago. These results are consistent with the radiocarbon date from the top of the first phase terrace.

All of the soils created here were easily tilled loams or sandy loams, with the first phase terrace comprising slightly finer textured soils, and the second phase deposits being slightly coarser textured. Unlike the hard limestone terrains, the easily excavated Neogene marl is not an impediment to agricultural development and appears to have been used in both phases to provide sediment for terrace construction.

\subsubsection{Skariana (Sk1)}

This section is located on the road to the modern cluster of houses at Skariania (figure 1, Sk1), close to some of the only olive groves on the island and an area of modern beekeeping. The examined section is on the east side of the road, as it descends to the stream crossing, and is situated one terrace up from the stream channel. The parent material here is a very gravelly section of the Neogene marl. The exposure is about $1.5 \mathrm{~m}$ tall and consists of a thick terrace tread fill $(\sim 84 \mathrm{~cm}$ thick) resting upon a thin, very organic rich buried soil at depth. The terrace fill deposits contained a considerable quantity of relatively fine gravel but the gravel free texture of this soil is an easily tilled sandy loam. The A-horizon beneath the terrace fill contained considerably more clay than the tread fill and appears to have formed within an older argillic horizon, parts of which are still present beneath the now buried top soil. The argillic horizon is a reddish brown color and ranged in texture from a clay to a sandy clay loam (figure 13).

This exposure appears to represent a single phase of terrace construction and the two OSL samples indicate that this most likely occurred in the century between $\mathrm{AD} 1708$ and $\mathrm{AD}$ 1808, and this is consistent with agricultural expansion following late $18^{\text {th }}$ century re-colonization of the island. The bulk radiocarbon age on the buried soil beneath the terrace fill yielded an age of $430 \pm 40$ years BP (Beta 248597) or cal AD 1429-1485) that is older than the OSL dates because it reflects the mean residence age of organic carbon in this soil. The soil formed within the terrace fill contains about the same amount of organic matter as the soil buried by terrace construction, but the modern terrace soil exhibits significantly less magnetic susceptibility enhancement, which is consistent with a relatively young age.

\subsection{Other circumstantial evidence}

It is notoriously difficult to date whole terrace systems using archaeological evidence alone, but in the light of our island-wide intensive survey, as well as the absolute dates and analysis above, it is still possible to make some suggestions. The earliest lithic scatters on Antikythera probably date to the $5^{\text {th }}$ or earlier $4^{\text {th }}$ millennium BC and are found in locations that do not suggest a need for terrace agriculture. Many of these scatters are probably associated with short-term seasonal visits to the island. By the latter part of the 3rd millennium if not before, there is evidence for more settled patterns of exploitation and by the $2^{\text {nd }}$ millennium BC, we find three or four parts of the island with a scatter of small farmsteads each. Contemporary evidence from the neighbouring island of Kythera (Krahtopoulou and Frederick 2008; see also Bevan 2002) and further 
afield from the island of Pseira on Crete (Hope Simpson et al. 2004) suggest that cross-channel terracing may have been a strategy that was developing in the $2^{\text {nd }}$ millennium, on Crete and amongst Cretan-affiliated communities such as those on Kythera and Antikythera.

The direct evidence for cross-channel terracing on Kythera and Pseira are based on unusual preservation and recovery situations (respectively, an unusually large road-cut in what has been a more lightly farmed part of the island in modern times, and a buried terrace found during an excavation on an island with very little later activity). We are thus not particularly surprised that such evidence has not come to light in our work on Antikythera, given the repeated use and disturbance of the Neogene landscapes preferred by Bronze Age Cretan communities, as well as the lack of very large road cuttings or major excavations. However, we suspect that the $2^{\text {nd }}$ millennium BC site locations on Antikythera do imply limited cross-channel investment of this kind, as they are often next to shallow channels of Quaternary alluvium. Thereafter, a clear phase of renewed activity occurs from the late $4^{\text {th }}$ to mid $1^{\text {st }}$ century B.C. when a nucleated settlement was built on the north coast of the island. This has traditionally been associated with piratical activities and our intensive survey of the whole island suggests only a very few finds beyond this zone. However, the OSL date of 400$140 \mathrm{BC}$ from Ch1 as reported above, may conceivably suggest limited landscape investment in the mid 1st millennium BC, and if so, it might argue that contemporary Hellenistic inhabitants engaged in a wider set of activities than is traditionally suggested.

Following a period of abandonment, the next major phase of island occupation is during the late $4^{\text {th }}-7^{\text {th }}$ centuries $A D$ when there are several small Late Roman villages and hamlets. While these settlements prioritised access to the flatter land on the island, the quantities of Late Roman pottery that we still find in hillslope terrace fills cannot always be explained by eroding settlement deposits or flat field agriculture nearby and are likely to indicate some degree of terraced cultivation, even if our sample of absolute dates does not document it directly. After another period of complete or near complete abandonment, the next visible phase of settlement is around the $12-13^{\text {th }}$ century AD, and perhaps a century to either side. This peak of activity broadly matches the date of the lowest terrace deposit near the church of Agios Myronas, and perhaps also a fairly isolated field system on the central eastern side of the island (figure 2, 'Sochoria') where we have found good evidence for 12-13 th century activity, but without the same intensity of later $19^{\text {th }}$ century settlement. Undoubtedly some $19^{\text {th }}$ century exploitation of this area occurred, but there remains a good chance that the elaborate system of enclosed fields, terraces and drove-ways in this vicinity were primarily formed during this Middle Byzantine phase.

Thereafter, there is a little $15^{\text {th }}-16^{\text {th }}$ century AD material, but the bulk of the archaeological evidence suggests that the island was largely abandoned. Passing travellers also repeatedly declare it uninhabited over much of the $15^{\text {th }}$ to late $18^{\text {th }}$ centuries. This combination of negative evidence makes the 15 th or 16 th century $\mathrm{AD}$ absolute dates from the M1 and $\mathrm{CH} 1$ terrace deposits difficult to interpret, but the dated soils may come from post-abandonment erosion or 
match small-scale activity respresented by the few $15^{\text {th }}-16^{\text {th }}$ century finds mentioned above. However, by far the best-preserved evidence for terrace systems comes from the latest period of late $18^{\text {th }}$ century resettlement. Most of the terraced field systems have a light scatter of late $18^{\text {th }}$ to $20^{\text {th }}$ century pottery that probably arrived in the field as the combined result of household waste used for manuring, and accidental breakage by field labourers. The historical data suggest a period of agricultural investment at the time of initial colonisation in the late $18^{\text {th }}$ century, particularly in the central, flattest and most fertile parts of the island, with a second phase of reinvestment and expansion in the second quarter of the $19^{\text {th }}$ century. The error margins associated with the radiocarbon dates do not allow us to be certain, but the dates from M2 and Sk1 do seem to fall within the first of these stages while the latest terrace deposit from Ch1 may fall into the second, alongside the range of single phase investments we see on the harder limestones (e.g. D1 and D2).

\section{Discussion}

Although the detailed discussion above will be of interest for Mediterranean landscape historians, we also feel that thrse observations are of wider relevance in the discussion of landesque investment and niche construction. Clear patterns exist between the parts of the landscape that are terraced and the underlying island environment, as well as a complicated relationship with human demographic cycles. We also suspect that further patterns of variability reflect different cultural traditions of terrace-building, differing for example between those imported from western Crete and versus others from Kythera, though this is difficult or impossible to substantiate with the present dataset.

Crucially however, while we can certainly suggest a coarse correlation between terrace-building and periods of more substantial settlement on the island, we have found little evidence to support a model in which population pressure, at a small (e.g. decadal) scale, is the prime mover behind terrace construction. Likewise there is little evidence for population pressure or terrace abandonment as a factor behind accentuated erosion patterns. In both cases we would argue, broadly in line with comments by Karl Butzer (2005), that the background mechanisms are usually complex and historically variable, but typically involve a constellation of several interacting factors. In fact, large-scale continuous erosion does not seem to be a major problem on the Antikytheran landscape beyond the obvious impact that larger rain storms have on portions of the landscape that have broken terrace walls. This is likely due to the relatively rapid recolonisation of former terraced slopes by stabilising vegetation (Palmer et al. 2010) that, despite extensive grazing by feral goats, has established itself over much of the island since intensive agricultural activity ceased several decades ago. This simple cycle of land clearance, terrace construction and then often intensive cultivation, followed by abandonment and re-colonization by vegetation has happened several times in Antikythera's past. Indeed, we have documented super-imposed cycles of terracing in the more fertile areas, while there are also pockets of single phase terracing that provide an extensive window on a past phase of capital investment that is difficult to identify elsewhere. Dating these systems remains very tricky, but our joint use of archaeological, geomorphological and chronometric data is we suggest, a useful way forward. 
Turning to wider debates about sustainable landscape investment, in many ways, it is the first few years after the abandonment of fields that is a crucial and under-appreciated aspect of the issue, as our work has shown how quickly vegetation can establish itself on previously cultivated land. Put simply, it is not long-term, multi-generational abandonment of fields that is really the problem but far shorter-term abandonments that are a feature of crop rotation strategies, shifting sedentary strategies and various historically contingent and abrupt shifts in population. Over longer time frames, decades and centuries, perennial plants reassert themselves, and offer physical protection in the form of canopy, leaf litter and improved soil structure due to increased organic content. Very old abandoned fields often therefore approach the phytosociological profile and erosion properties of natural soils. Prior to this recolonisation, annual flowering plants (which provide poor protection) predominate and abrupt changes in the degree of animal grazing are likely.

Another point to emphasise is that over longer periods of abandonment, reuseable landscape capital (e.g. traces of walled fields, stone clearance, etc.) also persists as a set of potential attractors for subsequent visitors and eventually renewed settlement and agricultural investment. This observation provides a powerful explanation for why we often see two or more discontinuous phases of activity, each potentially separated by several centuries, in the same general vicinity or even palimpsested. In short, field clearance and terrace construction are a form of niche construction that have very long-term impacts on the landscape. Subsequent settlers exploiting the same region, even after several centuries of abandonment, will be naturally drawn to these areas because a portion of the previous labour investment remains; and the signs of previous farming activity would undoubtedly also provide an indication to newcomers that what well might be an unknown landscape is likely to have agricultural potential.

Terraces are thus far more than simply topographically prominent built features of the rural Mediterranean: they are crucial parts of the evolution of the social and ecological landscape. As such, they deserve considerable research investment to understand how different historical and environmental contexts affect their cycles of construction, use and abandonment. This research priority carries further urgency given modern Mediterranean patterns of increased agricultural mechanisation, demographic flux and economic change. 


\section{Figures}

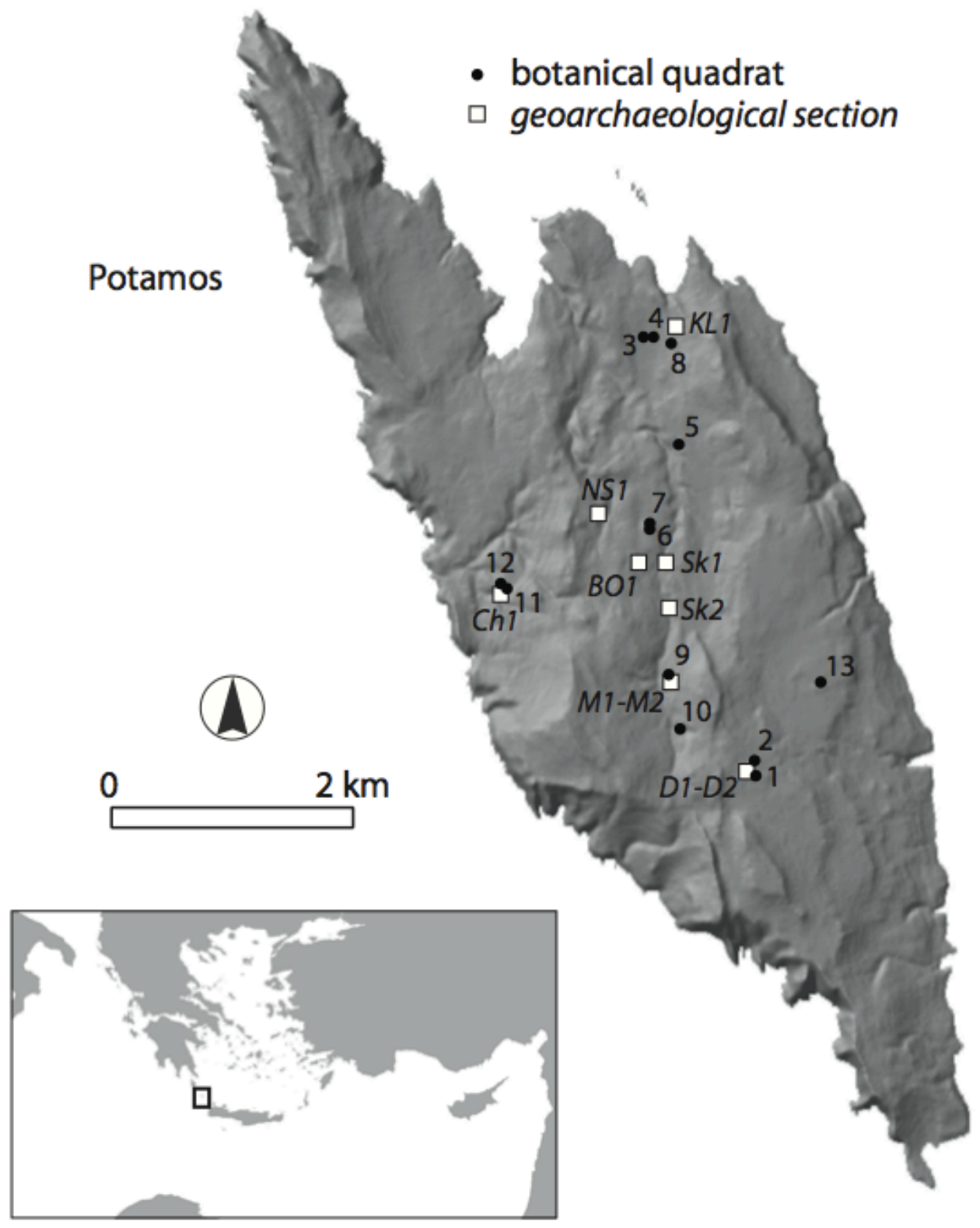

Figure 1. A map of Antikythera showing the geoarchaeological exposures, botanical quadrats and general locations mentioned in the text. 


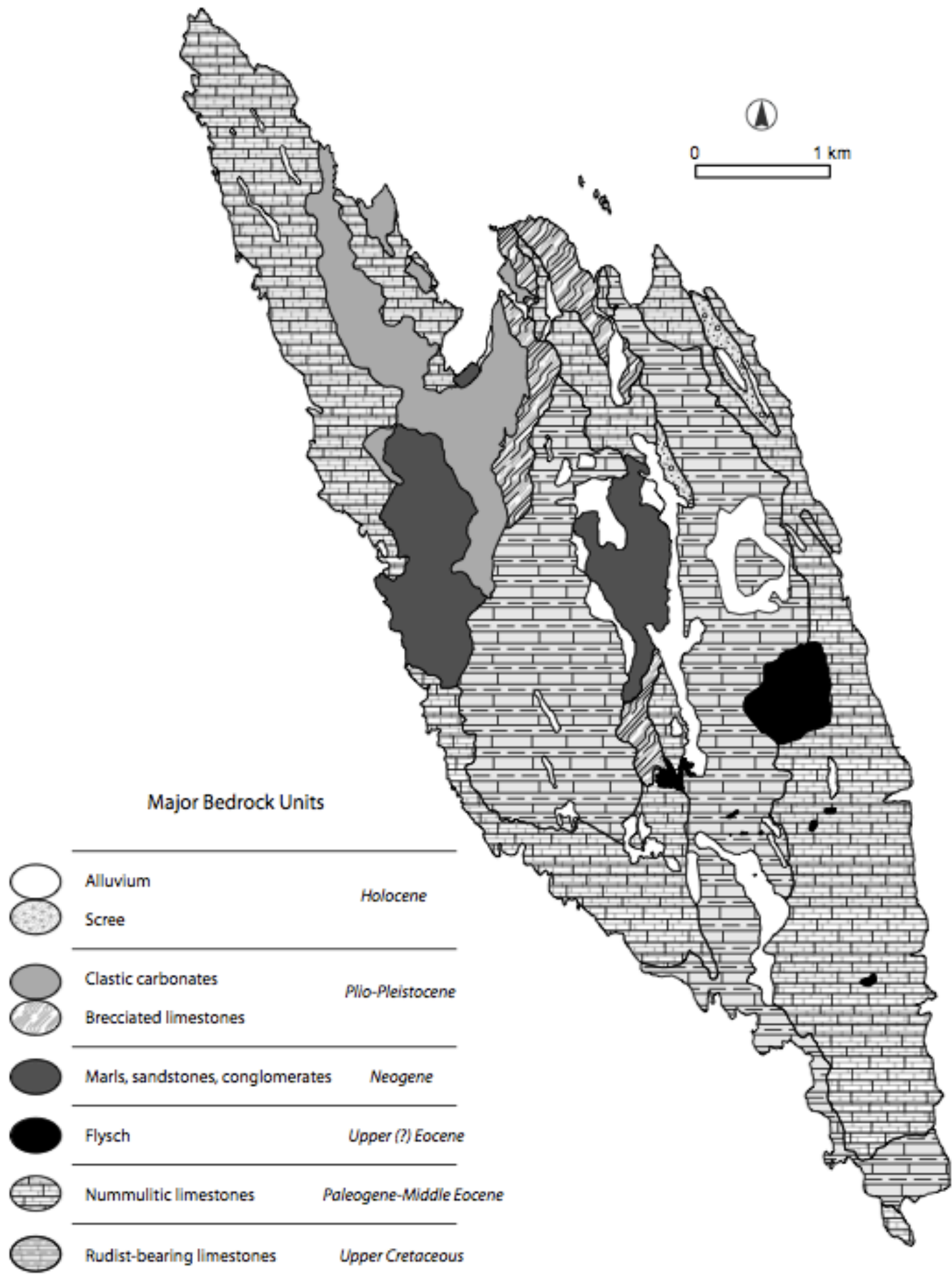

Figure 2. A map of bedrock geology (strips of alluvium are more common than shown and are only mapped here where they overlie the harder limestone areas). 

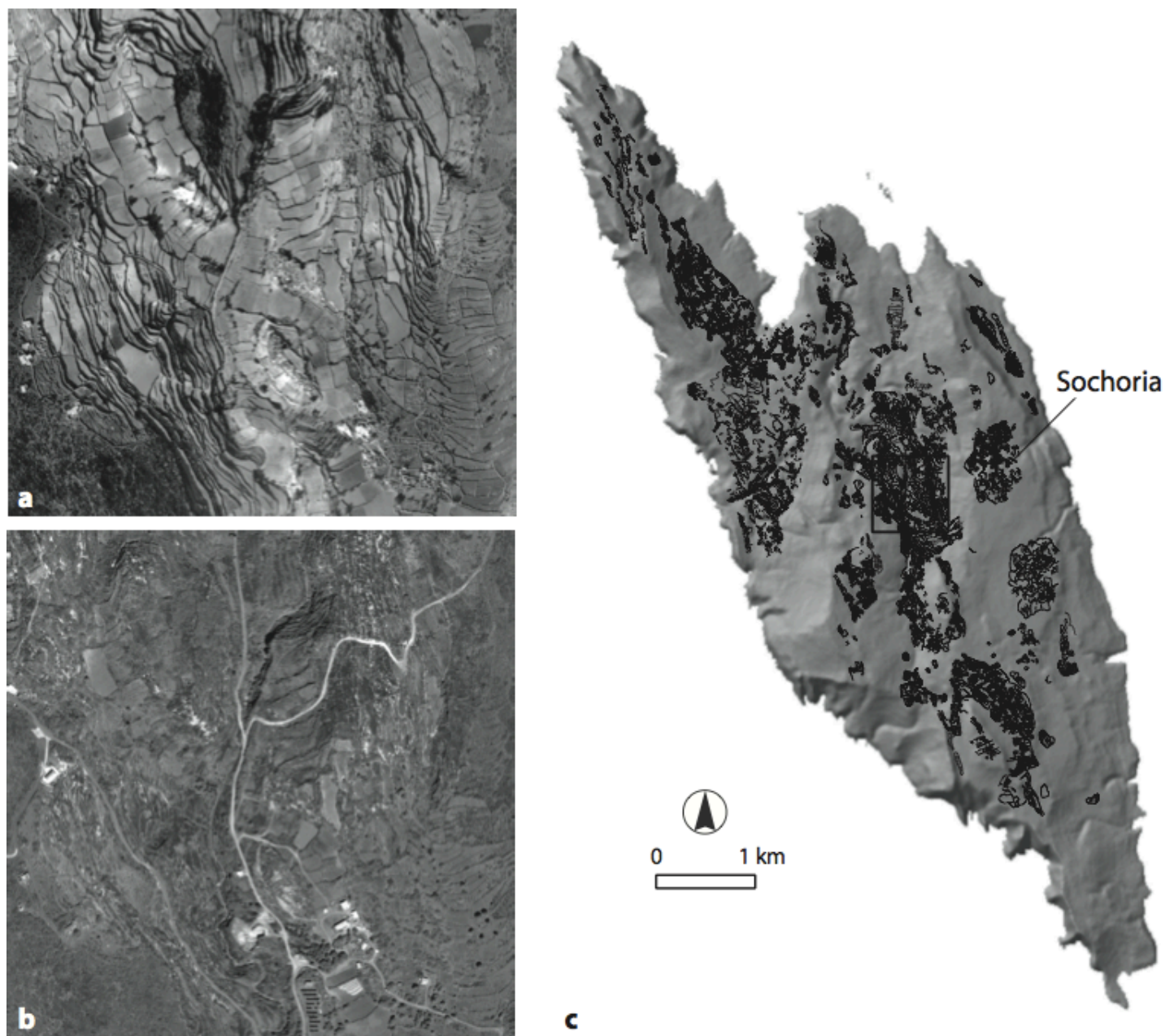

Figure 3. Terrace mapping: a) an aerial photograph from February 1944 just before the forced removal of the island's inhabitants to Crete (courtesy of the Aerial Reconnaissance Archive), b) a Quickbird panchromatic image of the same area from 2004 (courtesy of Digital Globe/Eurimage), c) a complete mapping of the ca. 12,000 field walls and terrace risers as visible in a combination of imagery and systematic field survey. 

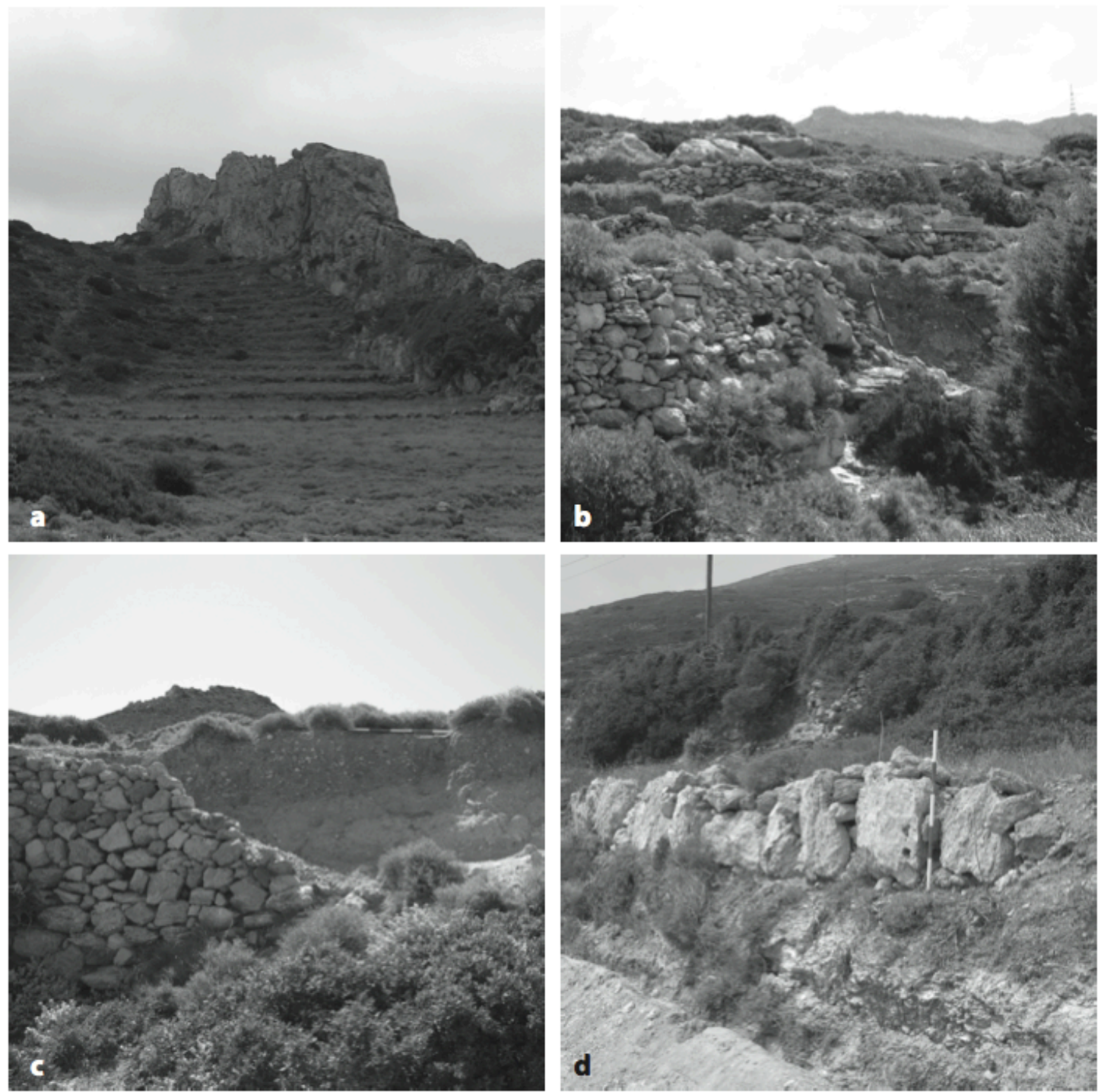

Figure 4. Terrace types and riser construction techniques: a) low cross-channel terraces in a tectonic valley on hard Cretaceous limestone, b) higher hillslope terraces collapsing on Neogene marl limestone (the Ch1 section is by the ranging pole in the foreground), c) a collapsed riser from a deep cross-channel terrace made entirely of even-sized Neogene limestone cobbles with at least two buried soil horizons behind it, and d) a riser from a hillslope terrace made of a basal course of large Neogene limestone slabs filled with smaller stones (the B01 section is just out of view to the right). 


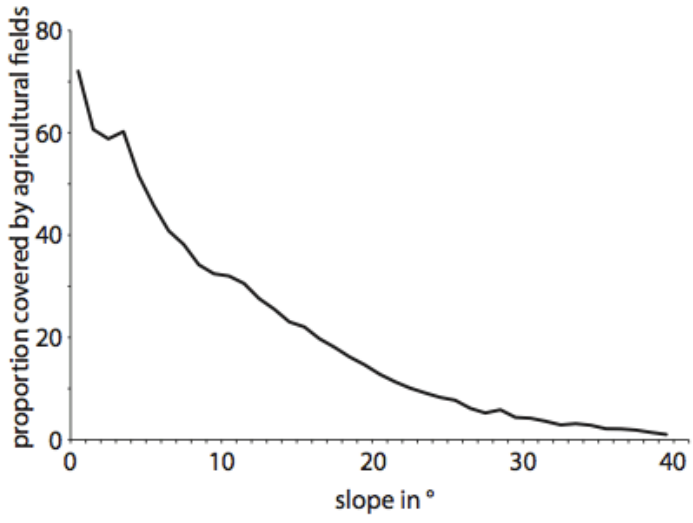

a

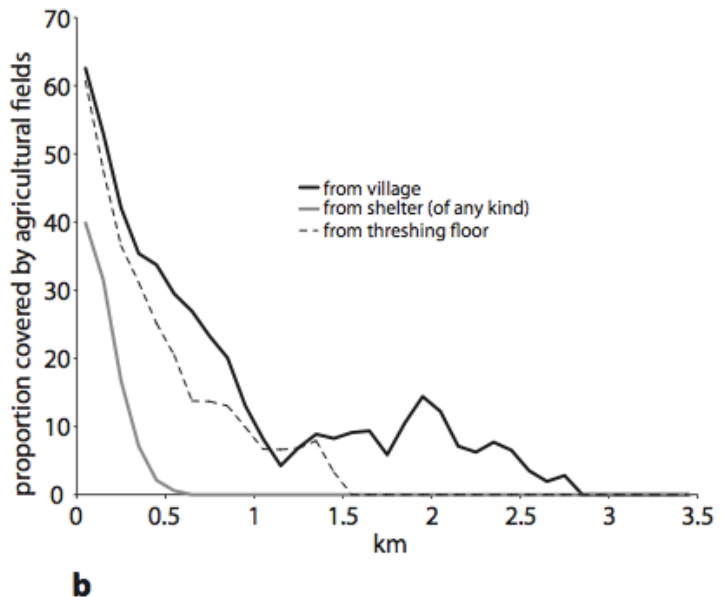

b

Figure 5. Two simple aggregate patterns exhibited by the location of agricultural fields, in relation to: (a) slope and (b) distance to the contemporary built structures. 

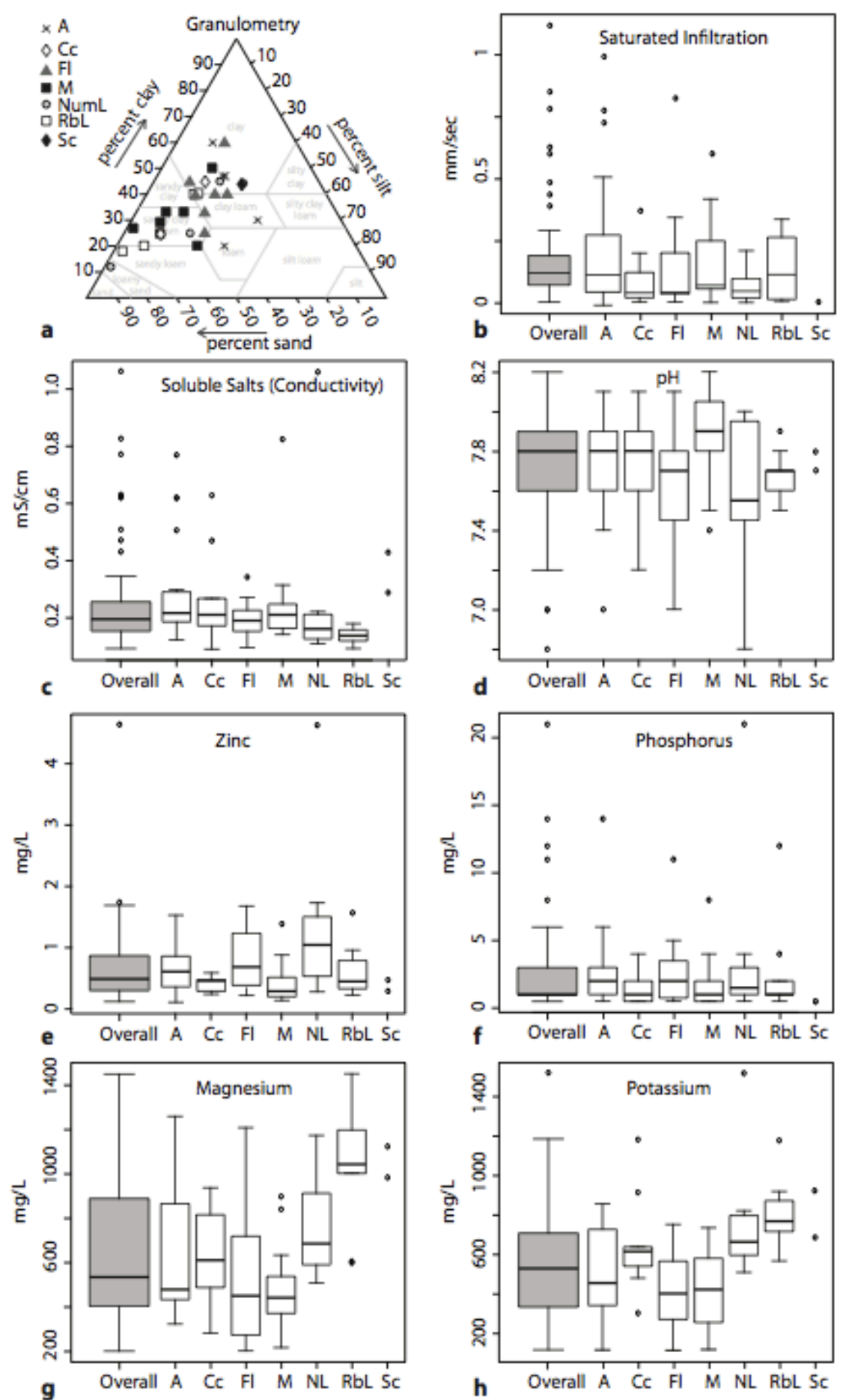

Figure 6. Soil chemistry: a) granulometry, b) saturated infiltration c) soluble salts and conductivity d) $\mathrm{pH}$, e) zinc, f) phosphorus, g) magnesium, and h) potassium. For each plot, the overall distribution of values is shown in grey $(\mathrm{n}=88)$ alongside a breakdown by parent bedrock geology: $A=$ alluvium $(n=21), C c=$ clastic carbonates $(n=9)$, Fl=flysch $(n=16), M=$ marls, sandstones and conglomerates $(\mathrm{n}=23), \mathrm{NumL}=$ nummulitic limestones $(\mathrm{n}=8), \mathrm{RbL}=$ rudist-bearing limestones $(n=9)$ and Sc=scree $(n=2)$. Granulometry was only performed on a sub-sample $(n=35)$. The boxes show the median and interquartile range; with those outlying values more than 1.5 times the interquartile range shown as open circles (the latter symbol is also used for individual points in the very small scree sample). Soil chemistry and granulometry courtesy of Guelph and A\&L laboratories (Canada) respectively. 

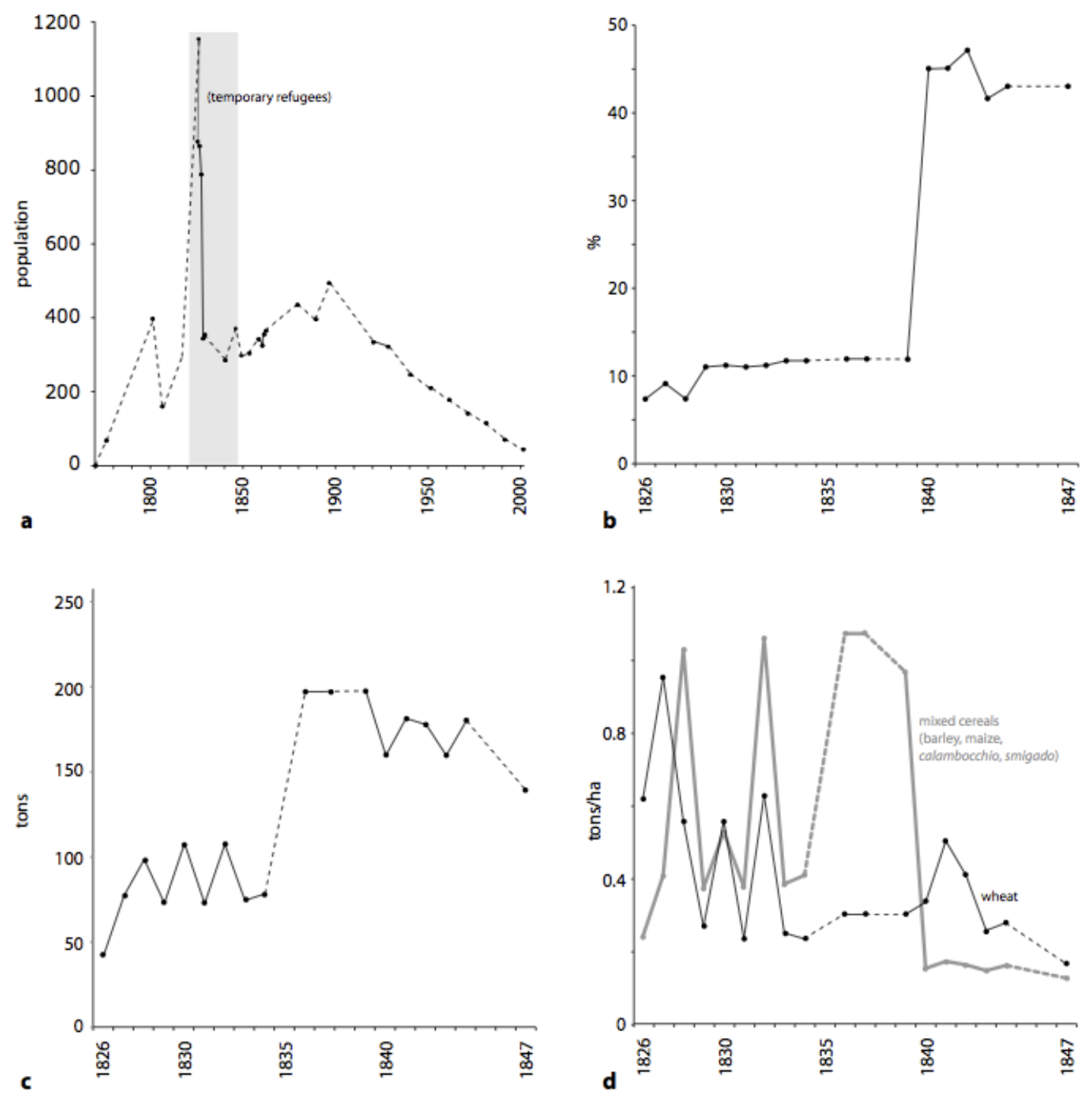

Figure 7. Demography and $19^{\text {th }}$ century agricultural expansion: a) population from ca.1770 to present (the grey-shaded area is the time period covered by the other charts in this figure), b) proportion of the island under cultivation or one-year fallow (1826-1847, total island extent is 20.8 square $\mathrm{km}$ ), c) total cereal production (1826-47), and d) wheat and mixed cereal yields (1826-47). Dotted lines cover multiple years over which annual records are unavailable. Sources: UK National Archives, Colonial Office 136/1332-40, National Statistical Service of Greece. 

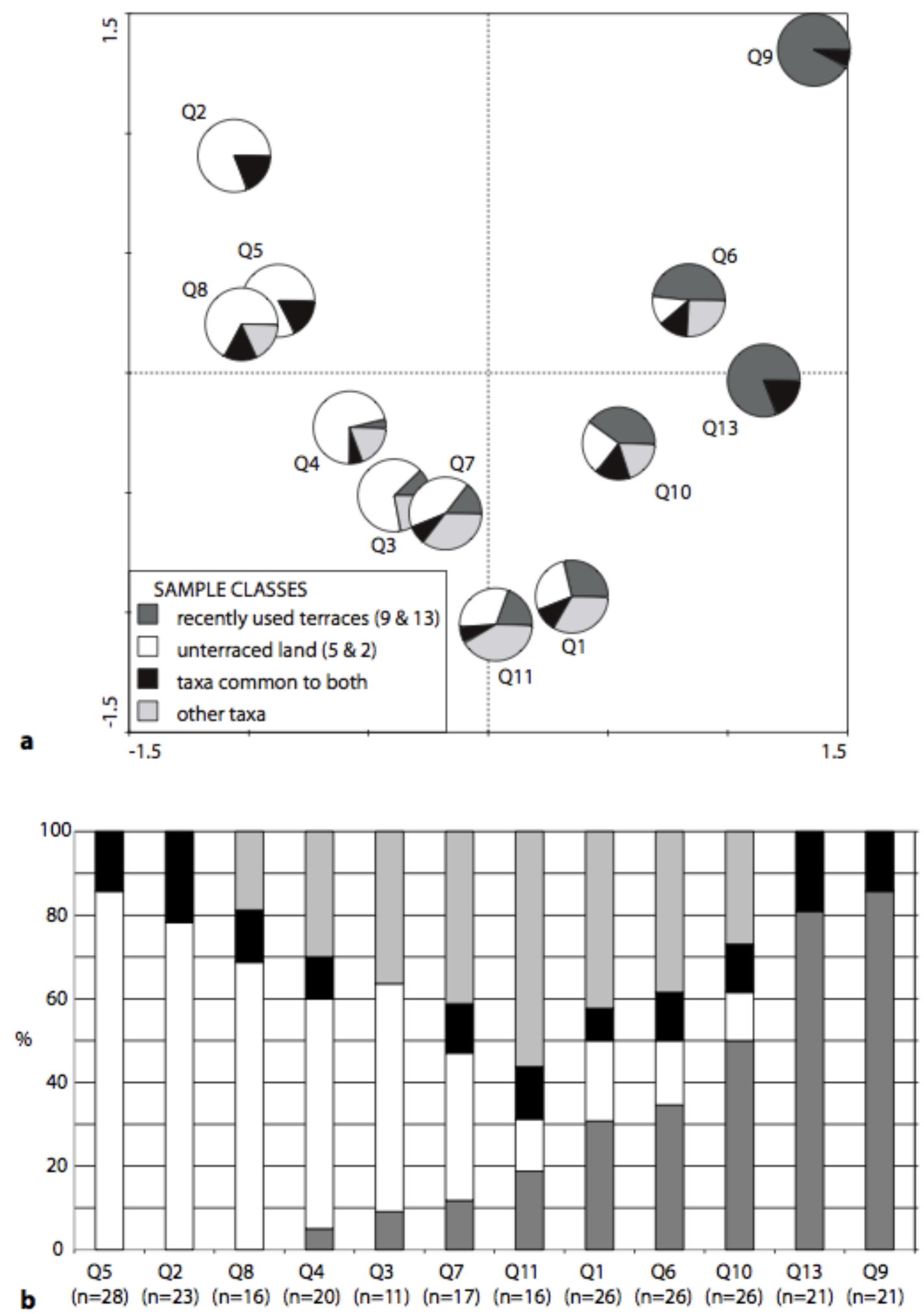

Figure 8. Terrace abandonment and recolonising vegetation: a) a correspondence analysis plot of the relative abundance scores for 120 plant taxa in 12 sampled quadrats (outlier Q12 is omitted) using pie charts to show the proportional representation of taxa present on the recently used land, on the unterraced plots, those common to both and taxa only found on the other terraces, b) a bar chart showing presence/absence data for the taxon groupings shown in a) arranged in descending order from left to right along the $\mathrm{x}$ axis according to the percentage presence of those taxa common to recently used terraces $(n=$ number of taxa identified per quadrat). 

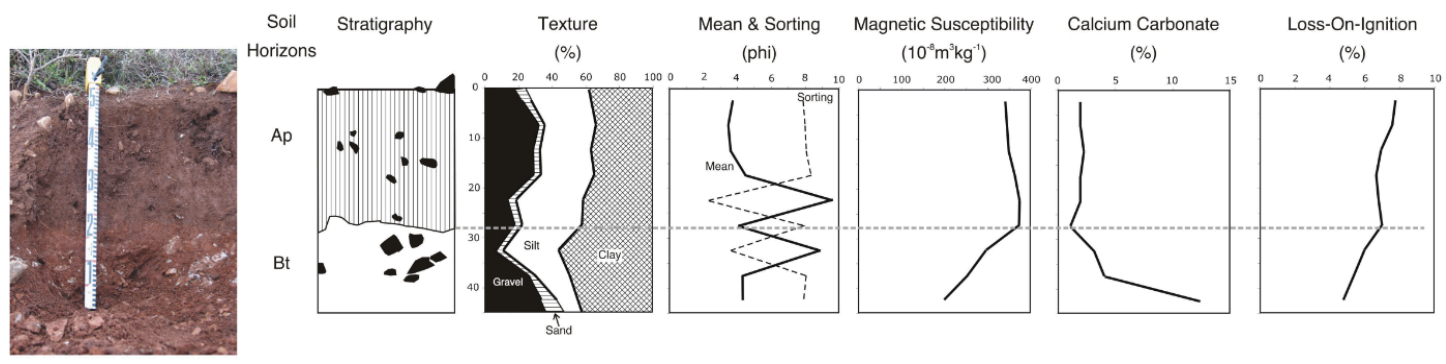

1. Profile drawing of terrace deposits at Domata plateau (D1-D2)

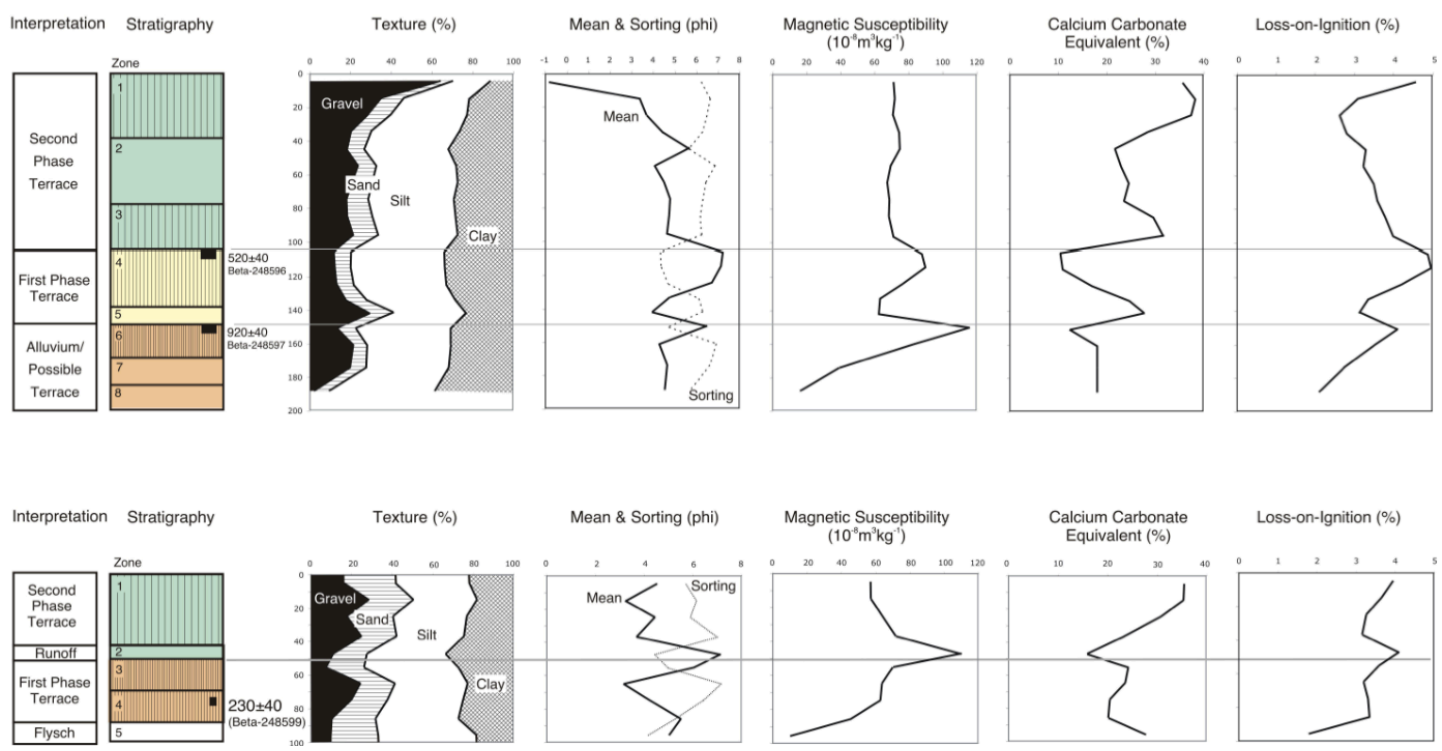

Figure 9. Profile drawings of terrace deposits at Galaniana (M1-2) 


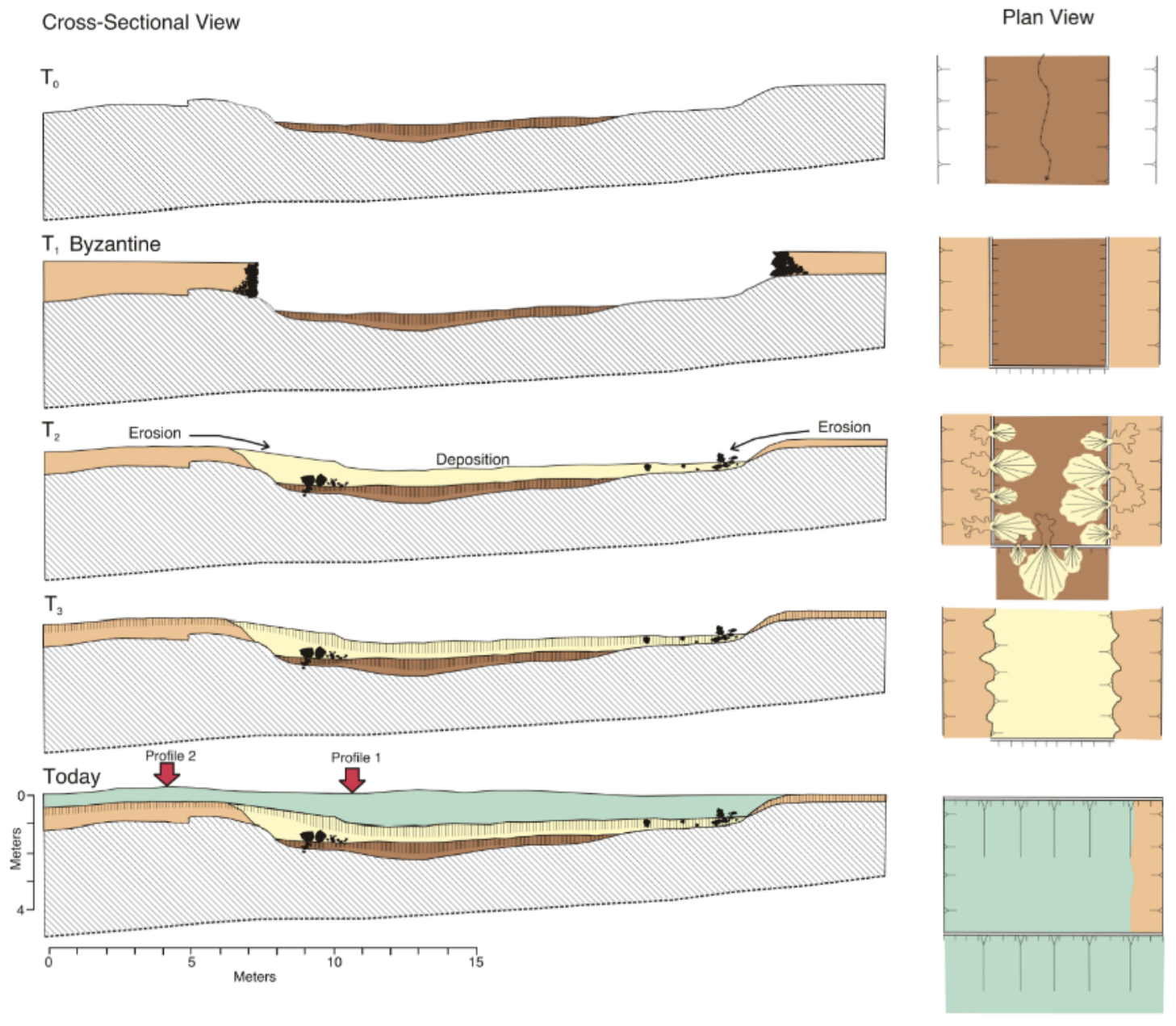

Figure 10. Schematic reconstruction of terrace development at Galaniana

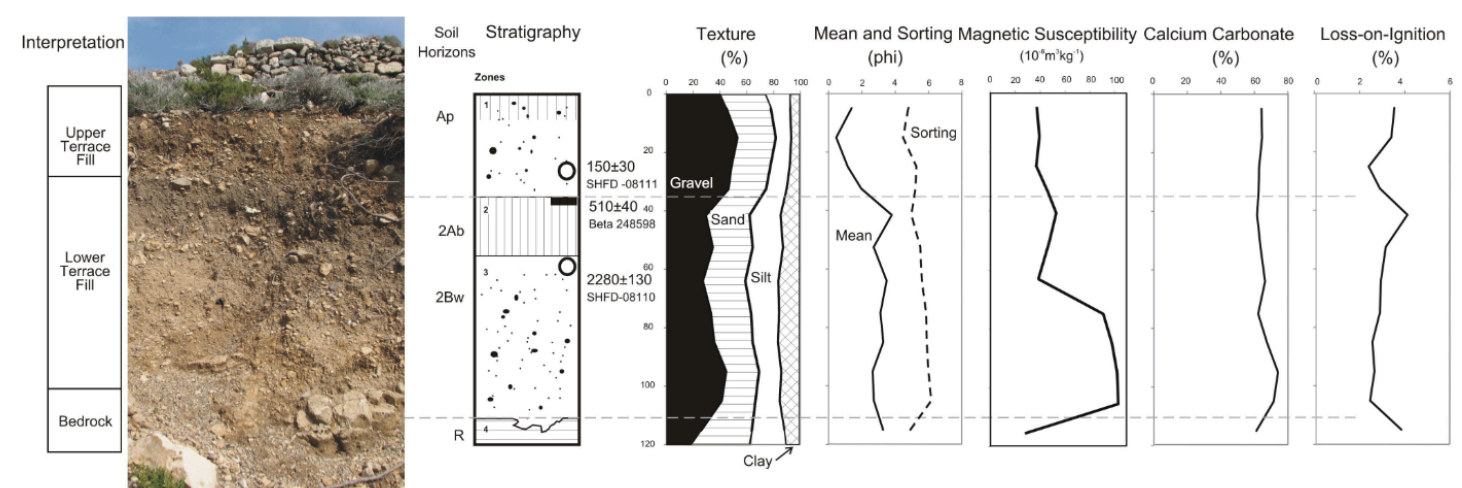

Figure 11. Profile drawing of terrace deposits at Charchaliana (Ch1) 


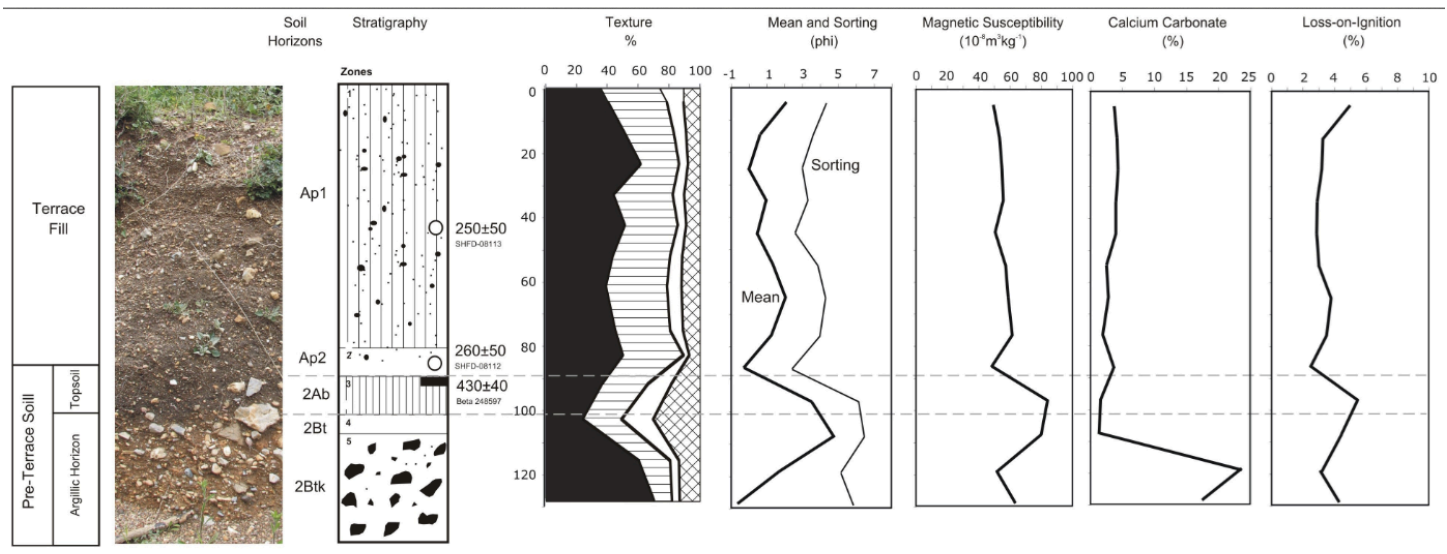

Figure 12. Profile drawing of terrace deposits at Skariana (Sk1). 


\section{Supplementary Data}

\begin{tabular}{|c|c|c|c|c|c|c|}
\hline $\begin{array}{l}\text { Field } \\
\text { ID }\end{array}$ & Lab No. & $\begin{array}{l}\text { Depth } \\
\text { from } \\
\text { Surface }\end{array}$ & $\begin{array}{l}\text { Useable } \\
\text { Grains }\end{array}$ & De (Gy) & $\begin{array}{l}\text { Dose } \\
\text { Rate } \\
\left(\mu G y / k^{-}\right. \\
\text {1) }\end{array}$ & Age $( \pm 1 \sigma)$ \\
\hline $\begin{array}{l}\text { CH1- } \\
\text { OSL1 }\end{array}$ & Shfd08110 & $-60 \mathrm{~cm}$ & 35 & $2.84 \pm 0.1$ & $\begin{array}{l}1244 \\
\pm 54\end{array}$ & $\begin{array}{ll}272 & \text { BC } \\
\pm 130\end{array}$ \\
\hline $\begin{array}{l}\text { CH1- } \\
\text { OSL2 }\end{array}$ & Shfd08111 & $-27 \mathrm{~cm}$ & 21 & $\begin{array}{l}0.17 \\
\pm 0.03\end{array}$ & $\begin{array}{l}1154 \\
\pm 50\end{array}$ & $\begin{array}{ll}1858 & \mathrm{AD} \\
\pm 30 & \end{array}$ \\
\hline $\begin{array}{l}\text { SK1- } \\
\text { OSL1 }\end{array}$ & Shfd08112 & $-85 \mathrm{~cm}$ & 31 & $\begin{array}{l}0.35 \\
\pm 0.03\end{array}$ & $\begin{array}{l}1329 \\
\pm 61\end{array}$ & $\begin{array}{ll}1748 & \mathrm{AD} \\
\pm 30 & \end{array}$ \\
\hline $\begin{array}{l}\text { SK1- } \\
\text { OSL2 }\end{array}$ & Shfd08113 & $-50 \mathrm{~cm}$ & 15 & $0.3 \pm 0.06$ & $\begin{array}{l}1188 \\
\pm 53\end{array}$ & $\begin{array}{ll}1758 & \mathrm{AD} \\
\pm 50 & \end{array}$ \\
\hline
\end{tabular}

Table 3. OSL Samples run using the single grain method. All four samples exhibited very low naturally-acquired OSL, were well-bleached prior to deposition and had not suffered from major disturbance since that time.

\begin{tabular}{|c|c|c|c|c|c|c|c|}
\hline $\begin{array}{l}\text { Fiel } \\
\text { d ID }\end{array}$ & $\begin{array}{l}\text { Beta } \\
\text { Lab } \\
\text { No. }\end{array}$ & $\begin{array}{l}\text { Materi } \\
\text { al }\end{array}$ & $\begin{array}{l}\text { Provenan } \\
\text { ce }\end{array}$ & $\begin{array}{l}\text { Measure } \\
\text { d Age }\end{array}$ & $\begin{array}{l}13 C / 12 \\
C\end{array}$ & $\begin{array}{l}\text { Convention } \\
\text { al Age }\end{array}$ & $\begin{array}{l}\text { Age } \\
( \pm \\
1 \sigma)\end{array}$ \\
\hline $\begin{array}{l}\text { M-1, } \\
\text { C14- } \\
2\end{array}$ & $\begin{array}{l}24859 \\
5\end{array}$ & soil & $\begin{array}{l}-146- \\
151 \mathrm{~cm}, \text { top } \\
\text { of zone } 6\end{array}$ & $\begin{array}{l}920+/- \\
40 \mathrm{BP}\end{array}$ & $\begin{array}{l}-24.7 \\
\text { o/oo }\end{array}$ & $\begin{array}{l}920+/-40 \\
\mathrm{BP}\end{array}$ & $\begin{array}{l}\text { AD } \\
1042 \\
- \\
1159\end{array}$ \\
\hline $\begin{array}{l}\text { M-1, } \\
\text { C14- } \\
1\end{array}$ & $\begin{array}{l}24859 \\
6\end{array}$ & soil & $\begin{array}{l}-104- \\
109 \mathrm{~cm}, \text { top } \\
\text { of zone } 4\end{array}$ & $\begin{array}{l}520+/- \\
40 \mathrm{BP}\end{array}$ & $\begin{array}{l}-24.8 \\
o / 00\end{array}$ & $\begin{array}{l}520+/-40 \\
\mathrm{BP}\end{array}$ & $\begin{array}{l}\mathrm{AD} \\
1333 \\
- \\
1439 \\
\end{array}$ \\
\hline SK-1 & $\begin{array}{l}24859 \\
7\end{array}$ & soil & $\begin{array}{l}-91-95 \mathrm{~cm}, \\
\text { zone } 3 .\end{array}$ & $\begin{array}{l}430+/- \\
40 \mathrm{BP}\end{array}$ & $\begin{array}{l}-24.8 \\
o / 00\end{array}$ & $\begin{array}{l}430+/-40 \\
\mathrm{BP}\end{array}$ & $\begin{array}{l}\mathrm{AD} \\
1429 \\
- \\
1485 \\
\end{array}$ \\
\hline $\begin{array}{l}\mathrm{CH}- \\
1\end{array}$ & $\begin{array}{l}24859 \\
8\end{array}$ & soil & $\begin{array}{l}-36-40 \mathrm{~cm} \text {, } \\
\text { top of zone } \\
2 .\end{array}$ & $\begin{array}{l}510+/- \\
40 \mathrm{BP}\end{array}$ & $\begin{array}{l}-24.8 \\
o / o 0\end{array}$ & $\begin{array}{l}510+/-40 \\
\text { BP }\end{array}$ & $\begin{array}{l}\mathrm{AD} \\
1404 \\
- \\
1440\end{array}$ \\
\hline $\begin{array}{l}\text { M2- } \\
1\end{array}$ & $\begin{array}{l}24859 \\
9\end{array}$ & $\begin{array}{l}\text { charcoa } \\
\text { l }\end{array}$ & $-76 \mathrm{~cm}$ & $\begin{array}{l}380+/- \\
40 \mathrm{BP}\end{array}$ & $\begin{array}{l}-34.3 \\
0 / 00\end{array}$ & $\begin{array}{l}230+/-40 \\
\mathrm{BP}\end{array}$ & $\begin{array}{l}\mathrm{AD} \\
1641 \\
- \\
1951 \\
\end{array}$ \\
\hline
\end{tabular}

Table 4. AMS Radiocarbon Samples (Calibrated with Calib 6.0 intcal09.14c) 


\section{Acknowledgements}

We would like to thank the Greek Ministry of Culture and the Greek Institute for Geology and Mining, as well as our three primary external funding agencies over the duration of the overall Antikythera Survey Project - the Social Science and Humanities Research Council (SSHRC) of Canada, the UK Arts and Humanities Research Council (AHRC) and the Institute for Aegean Prehistory (INSTAP). Dedicated funding for this work in particular was provided through an AHRC Landscape and Environment grant (AH/ E502989/1). Our archaeological sponsor in Athens has been the Canadian Institute in Greece and we are grateful to Jonathan Tomlinson for his assistance throughout. Aris Tsaravopoulos (ASP co-director, Greek Archaeological Service) offered extremely helpful guidance at various stages. We are also grateful to Cyprian Broodbank, Evangelia Kiriatzi and Nancy Krahtopoulou (Kythera Island Project) for discussions about terracing and other issues. Mark Bateman from the luminescence laboratory at the Sheffield Centre for International Drylands Research (SCIDR) kindly undertook the OSL dating and Guelph Laboratories were responsible for the bulk soil analysis from surface samples shown in figure 6 . The terracing dataset is archived with the UK Archaeology Data Service (doi: 10.5284/1012484).

\section{References}

Bevan A, Frederick C, Krahtopoulou N. A digital Mediterranean countryside: GIS approaches to the spatial structure of the post-medieval landscape on Kythera (Greece). Archeologia e Calcolatori 2003; 14: 217-36.

Bevan A, Conolly J, Tsaravopoulos A. The Fragile Communities of Antikythera. Archaeology International 2008; 10: 32-6.

Bevan A, Conolly J. Modelling spatial heterogeneity and nonstationarity in artifact-rich landscapes. Journal of Archaeological Science 2009; 36: 956-64.

Bevan, A. and Conolly, J. 2011. Terraced fields and Mediterranean landscape structure: an analytical case study from Antikythera, Greece, Ecological Modelling 222: 1303-1314.

Blaikie P, Brookfield H. Land Degradation and Society. London: Methuen; 1987.

Bohn, H.L., McNeal, B.L., and O'Conner, G.A. 2001. Soil Chemistry. 3rd Edition. Hoboken, NJ: John Wiley and Sons.

Bouyoucos, G. 1922. A Study of the Fertility of the Soils of Greece, Soil Science 13. 2: 63-79.

Butzer K. Environmental history in the Mediterranean world: cross-disciplinary investigation of cause-and-effect for degradation and soil erosion. Journal of Archaeological Science 2005; 32: 1773-800. 
Christakis, K.S. 2008. The Politics of Storage. Storage and Sociopolitical Complexity in Neopalatial Crete, Philadelphia: INSTAP Academic Press.

Erikson, C.L. 2006. Intensification, political economy, and the farming community: in defense of a bottom-up perspective of the past. In Marcus, J. and Stanish, C. (eds.) Agricultural Strategies. Los Angeles: Cotsen Institute of Archaeology. pp. 334-363.

Fuchs, M. 2007. An assessment of human versus climatic impacts on Holocene soil erosion in Northeast Peloponnese, Greece. Quaternary Research 67/3: 349356.

Forbes, H. 2000. Dowry and inheritance: their relationship to land fragmentation and risk reduction on Methana. In Sutton, S.B. (ed.) Contingent Countryside: Settlement, Economy, and Land Use in the Southern Argolid Since 1700. Stanford: Stanford University Press. pp. 200-227.

Frederick C, Krahtopoulou A. Deconstructing agricultural terraces; examining the influence of construction method on stratigraphy, dating and archaeological visibility. In: Halstead P, Frederick C, editors. Landscape and Landuse in Postglacial Greece. Sheffield: Sheffield Academic Press; 2000, p. 79-94.

Krahtopoulou, A. and Frederick, C. 2008. The stratigraphic implications of longterm terrace agriculture in dynamic landscapes: polycyclic terracing from Kythera Island, Greece, Geoarchaeology 23.4: 550-585.

Galeos, A. and E. Drandaki 1993. Geological Map of Greece, Antikythera Island Sheet, scale 1:50.000. Athens: Institute of Geology and Mineral Exploration.

Grove AT, Rackham 0. The Nature of Mediterranean Europe: An Ecological History. Yale: Yale University Press; 2001.

Hope Simpson, R., Clark, J.A., Goldberg, P. (2004). The two agricultural terraces chosen for excavation. In Betancourt, P.P., Davaras, K. and Hope Simpson, R. (eds.) Pseira IX: The Pseira inland survey. Part 2: The Intensive Survey. Philadelphia: The Institute of Aegean Prehistory Academic Press. pp. 251-256.

James, P. Atherton, M., Harvey, A., Firmin, A., and Morrow, A. 1997. The physical environment of Methana: formation, exploitation and change. In Mee, C. and Forbes, H. (eds.) A Rough and Rocky Place: The Landscape and Settlement History of the Methana Peninsula, Greece. Liverpool: Liverpool University Press. pp. 5-32.

Jameson R Notes on the natural history and statistics of the island of Cerigo and its dependencies. The Edinburgh New Philosophical Journal 1836; 21: 263-79.

Leontsinis GN. The Island of Kythera. A Social History. Athens: Saripolos; 1987. 
Kokinou, E. and Kamberis, E. 2009. The structure of the Kythira-Antikythira strait, offshore SW Greece $\left(35.7^{\circ} \mathrm{E}, 36.6^{\circ} \mathrm{N}\right)$, Geological Society, London, Special Publications 311: 343-360.

Koulouri M, Giourga Chr. (2007) Land abandonment and slope gradient as key factors of soil erosion in Mediterranean terraced lands. Catena 69:274-281

Mazoyer, Marcel and Roudart, Laurence. A History of World Agriculture: From the Neolithic Age to the Modern Crisis (trans. James H. Membrez). New York: Monthly Review Press.

Odling-Smee, F.J., K.N. Laland and M.W. Feldman 2003. Niche Construction: The Neglected Process in Evolution. Princeton: Princeton University Press.

Palmer C, Colledge S, Bevan A, Conolly J. Vegetation recolonisation of abandoned agricultural terraces on Antikythera, Greece. Environmental Archaeology 2010; 15: 64-80.

Papanastasis VP 2007. Land abandonment and old field dynamics in Greece. In: Cramer, VA and Hobbs, RJ (eds) Old Fields: Dynamics and Restoration of Abandoned Farmland. Island Press, Washington

Price, S. and Nixon, L. 2005. Ancient Greek agricultural terraces: evidence from texts and archaeological survey. American Journal of Archaeology 109.4: 665694.

Rackham 0 2008. Holocene history of Mediterranean island landscapes. In: Vogiatzakis, IN, Pungetti, G and Mannion, AM (eds) Mediterranean Island Landscapes: Natural and Cultural Approaches. Springer, Dordrecht, pp 36-60

Sener, O. and Arslan, M. and Soysal, Y. and Erayman, M. 2009. Estimates of relative yield potential and genetic improvement of wheat cultivars in the Mediterranean region, Journal of Agricultural Science 147: 323-332.

Turland NJ, Fielding J; edited by Mathew, B. 2005. Flowers of Crete. Royal Botanic Gardens, Kew.

Tzanopoulos J, Mitchley J, Pantis J 2005 Modelling the effects of human activity on the vegetation of a northeast Mediterranean island. Applied Vegetation Science 8:27-38

Whitelaw T, French C. Soil erosion, agricultural terracing and site formation processes at Markiani, Amorgos, Greece: the micromorphological perspective. Geoarchaeology 1999; 14: 151-89.

Williamson, I. and M.D. Sabath 1984. Small Population Instability and Island Settlement Patterns, Human Ecology 12.1: 21-34 
Widgren M. Pre-colonial landesque capital: a global perspective. In: Hornborg A, McNeill JR, Martinez-Alier J, editors. Rethinking Environmental History: Worldsystem History and Global Environmental Change: Lanham: Altamira Press; 2007, p. 61-77. 